\title{
Endocrinology and the brain: corticotropin-releasing hormone signaling
}

\author{
Carolina Inda ${ }^{1,2}$, Natalia G Armando ${ }^{1}$, Paula A dos Santos Claro' ${ }^{1}$ and \\ Susana Silberstein ${ }^{1,2}$
}

${ }^{1}$ Instituto de Investigación en Biomedicina de Buenos Aires (IBioBA)-CONICET-Partner Institute of the Max Planck Society, Buenos Aires, Argentina

${ }^{2}$ DFBMC, Facultad de Ciencias Exactas y Naturales, Universidad de Buenos Aires, Buenos Aires, Argentina
Endocrine CONNECTIONS

\begin{abstract}
Corticotropin-releasing hormone $(\mathrm{CRH})$ is a key player of basal and stress-activated responses in the hypothalamic-pituitary-adrenal axis (HPA) and in extrahypothalamic circuits, where it functions as a neuromodulator to orchestrate humoral and behavioral adaptive responses to stress. This review describes molecular components and cellular mechanisms involved in $\mathrm{CRH}$ signaling downstream of its $\mathrm{G}$ protein-coupled receptors (GPCRs) CRHR1 and CRHR2 and summarizes recent findings that challenge the classical view of GPCR signaling and impact on our understanding of CRHRs function. Special emphasis is placed on recent studies of $\mathrm{CRH}$ signaling that revealed new mechanistic aspects of CAMP generation and ERK1/2 activation in physiologically relevant contexts of the neurohormone action. In addition, we present an overview of the pathophysiological role of the $\mathrm{CRH}$ system, which highlights the need for a precise definition of CRHRs signaling at molecular level to identify novel targets for pharmacological intervention in neuroendocrine tissues and specific brain areas involved in $\mathrm{CRH}$-related disorders.
\end{abstract}

Correspondence should be addressed to S Silberstein Email

ssilberstein@ibioba-mpspconicet.gov.ar

\section{Introduction}

The neuropeptide corticotropin-releasing hormone $(\mathrm{CRH}$, also named CRF) plays a key role in the integration of neuroendocrine, autonomic and behavioral responses to stress (1). Hypothalamic paraventricular CRH-secreting neurons are essential to the stress response driving both basal and stress-induced hypothalamic-pituitary-adrenal axis (HPA) activation. Besides the hypothalamus, CRH is widely distributed in extrahypothalamic circuits of the brain where it functions as a neuromodulator to establish and integrate a complex humoral and behavioral system that regulates multiple aspects of the stress response ( 1 , $2,3,4)$. Furthermore, a role for $\mathrm{CRH}$ as a regulator of neuronal structure is being recently appreciated in areas of the developing and mature brain (5). CRH system dysregulation is critically involved in stress-related disorders: psychiatric conditions (i.e. depression, anxiety, addictions), neuroendocrinological alterations and inflammation and has been reported to influence the onset and development of neurodegenerative diseases $(6,7)$.

$\mathrm{CRH}$ is a 41 amino acid peptide first characterized from ovine hypothalamus (8). The other members of the CRH family (9) in mammals are urocortin 1 (UCN1), urocortin 2 (UCN2) and urocortin 3 (UCN3) (Fig. 1). These peptide hormones and its receptors are ubiquitously present throughout mammalian tissues playing key roles in stress-mediated central and local effects. In the periphery $\mathrm{CRH}$ has an immunomodulatory role, being proinflammatory (10). http://www.endocrineconnections.org
DOI: 10.1530/EC-17-0111 (c) 2017 The authors Published by Bioscientifica Ltd

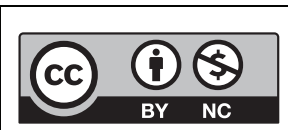

This work is licensed under a Creative Commons Attribution-NonCommercial 4.0 International License. 
A

Signal

Peptide

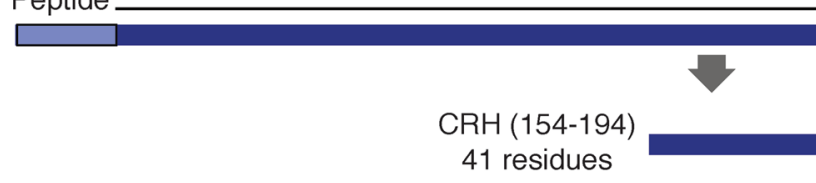

B

CRH SEEPPISLDLTFHLLREVLEMARAEQLAQQAHSNRKLMEII UCN1 DNPSLSIDLTFHLLRTLLELARTOSORERAEQNRIIFDSV UCN2 IVLSLDVPIGLLQILLEOARARAAREQATTNARILARV UCN3 FTLSLDVPTNIMNLLFNIAKAKNLRAQAAANAHLMAQI

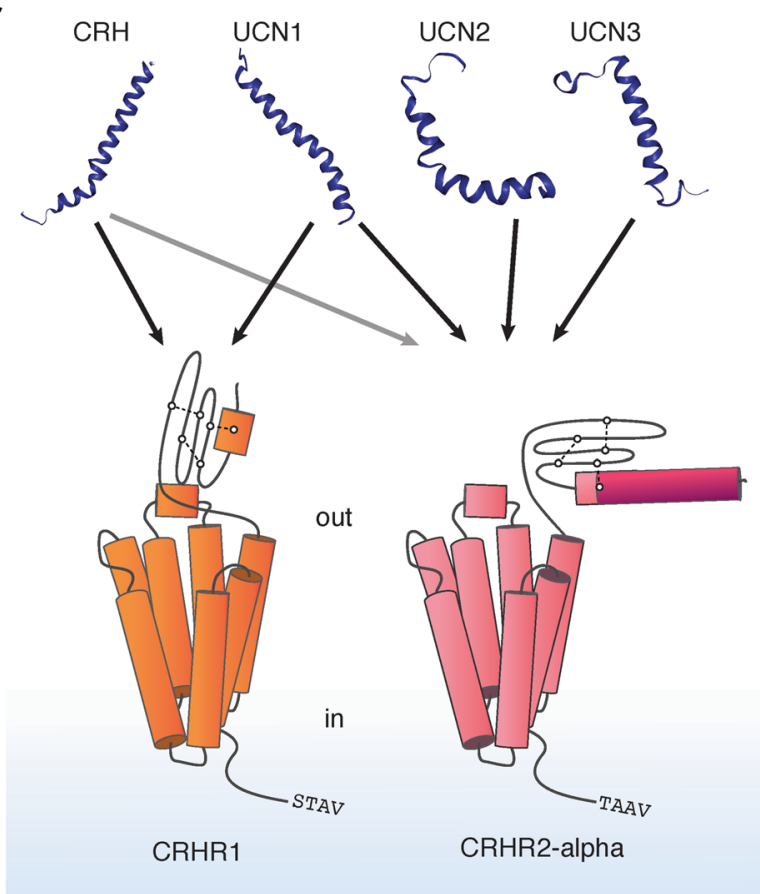

\section{Figure 1}

The main molecular components of the $\mathrm{CRH}$ system (A) Corticotropin-releasing hormone (CRH) is a 41-amino acid neuropeptide generated by proteolytic cleavage from a 194-amino acid precursor, followed by the amidation of the carboxyl terminus. (B) Amino acid sequence alignment of mammalian CRH family peptides that includes urocortins 1-3 (UCN1, UCN2, UCN3) showing regions of high amino acid conservation in boxes. Identical residues are marked in red. (C) Representation of corticotropin-releasing peptide receptors (CRHRs) based on structural data. Within the brain CRHR1 and CRHR2 $\alpha$ are the two receptors involved. A characteristic feature of class B GPCRs is a large ECD stabilized by three conserved disulfide bridges (white dots connected by dash lines) but only CRHR2 $\alpha$ contains a pseudo-signal peptide (dark pink). These receptors also differ in their carboxyl-terminal: the last four residues of CRHR1 (STAV) conform a PDZ domain, absent in CRHR2 (TAAV). Colored arrows show ligand-receptor interactions, with gray arrows indicating lower affinity. CRH binds to both receptors but with higher affinity to CRHR1. UCN1 is a high affinity ligand to both CRHR1 and CRHR2, whereas UCN2 and UCN3 are considered selective ligands for CRHR2.

The CRH system also includes the corticotropinreleasing hormone-binding protein (CRH-BP) expressed in peripheral tissues and the brain. Initially thought to bind free CRH and CRH-related ligands attenuating CRH receptors activation, its physiological role seems more complex and is still being investigated.

$\mathrm{CRH}$ and the CRH-related peptides operate through CRHR1 and CRHR2, which belong to the class B family of G protein-coupled receptors (GPCRs). A wealth of research has demonstrated that CRH and UCNs can signal through various intracellular pathways that depend on cellular context (11). Considering the promiscuous G protein coupling of CRHRs, it is not surprising that a plethora of molecular components has been implicated in CRHR functions, including ERK1/2 and p38 MAPKs, PKA, Akt, NFkB, GSK-3b/Wnt, RhoA as well as other important signaling molecules such as cAMP, calcium, IP3 and nitric oxide/cGMP (10).

Here, we review the principal characteristics of the CRH system and describe recent advances on the structural and functional features of CRHRs and ligands. Recent findings on CRHR1 signaling mechanisms are introduced in the context of the emerging model of GPCR function, which involves sustained signaling from intracellular compartments. We present a brief overview of important aspects of the CRH pathophysiology for which the identification of novel molecular components and mechanisms of CRHRs signaling will impact on development of therapies for CRH-related disorders.

\section{The CRH system: $\mathrm{CRH}$, the urocortins and their receptors}

\section{$\mathrm{CRH}$ and the activation of the Hypothalamic-Pituitary-Adrenal axis}

Hypothalamic CRH neurons drive both basal and stressinduced HPA activation, the main neuroendocrine system involved in stress responses. Stimuli that challenge homeostasis originated from visceral input or 
from external environmental changes are communicated to the CNS by neurochemical pathways and integrated at the hypothalamic level where they reach paraventricular (PVN) neurons controlling CRH secretion to the hypophyseal portal vessels that access the anterior pituitary gland (Fig. 2A). The binding of $\mathrm{CRH}$ to its receptors activates ACTH release from pituitary corticotrophs (1). ACTH stimulates the synthesis and release of glucocorticoids from the zona fasiculata of the adrenal cortex, cortisol in primates and corticosterone in rodents. The biological effects of glucocorticoids support the adaptation to stress-induced demands by controlling energy metabolism $(12,13)$. The adaptive function of the HPA depends on the negative feedback mechanisms that bring the HPA to baseline levels. Corticosteroids are released in a pulsatile ultradian pattern that may vary in amplitude and frequency under stressful conditions (14).

\section{Extrahypothalamic CRH: organization and integration of the stress response}

Intracerebroventricular CRH administration lead to anxiety-like behavioral and autonomic effects besides increasing ACTH release $(15,16,17,18)$. Behavioral aspects of the response seem independent of endocrine HPA axis-driven responses, since anxiety-related outcomes persisted in hypophysectomized rats (19). The differential expression of CRHRs and its ligands throughout the brain reflects the different actions that $\mathrm{CRH}$ exerts at the CNS level. A detailed anatomical map of expression of the $\mathrm{CRH}$ system components (ligands and receptors) in the CNS has been achieved integrating data obtained with a variety of technical approaches (see a detailed review in (20)).

Different than classic neurotransmitters, it is now accepted that $\mathrm{CRH}$ and its related peptides act as neuroregulators: without affecting synaptic efficacy or strength, they activate cell signaling processes that facilitate or depress neurotransmitters effect within specific neuronal circuits (21). The CRH system is anatomically and functionally connected with monoaminergic circuits that act in concert to convey stress signals to different brain areas to elicit a variety of responses to stress (21). The family of CRH and peptides and monoamines act through GPCRs, which rapidly modulate downstream effectors translating increases of ligands into altered functioning of neurons that express these receptors. CRH modulation

\section{A CRHR1 activation effects}

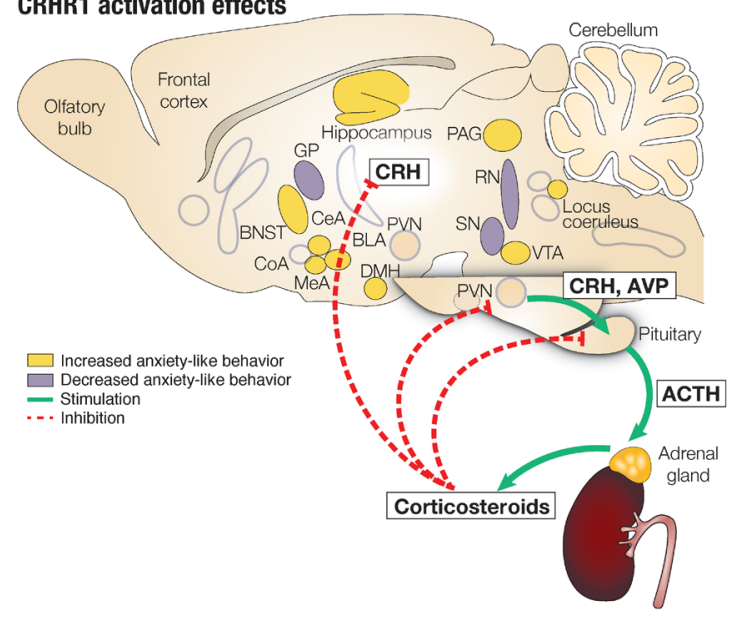

B

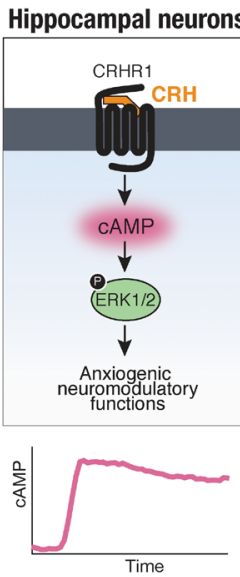

Corticotroph cells
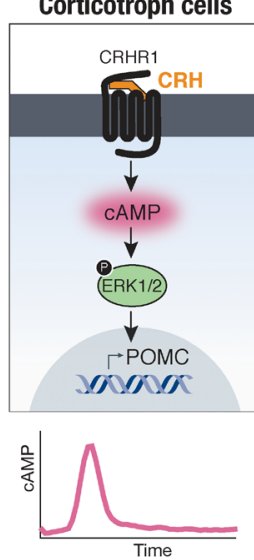
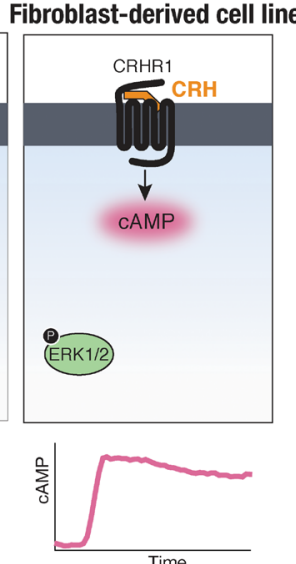

Figure 2

CRH/CRHR1 action at physiological and molecular levels (A) The HPA axis: CRH and AVP secreted from the hypothalamic PVN activate the release of ACTH from pituitary corticotrophs which, in turn, drives the synthesis and release of corticosteroids from the adrenal cortex. Corticosteroids exert a negative feedback on the hypothalamus and pituitary suppressing hormone secretion. $\mathrm{CRH}$ expression in extrahypothalamic circuits acts as a neuromodulator orchestrating a complex humoral and behavioral response to stress. The effect of CRHR1 activation on behavior depends on the brain area analyzed. In a sagittal section of the rodent brain, regions associated with increased anxiety-like behavior are shown in yellow and regions associated to reduced anxiety are in gray. It is suggested that a delicate balance between CRHR1-controlled circuits is necessary for a proper stress response and dysregulation of the system may lead to stress-related disorders. BLA, basolateral amygdala; BNST, bed nucleus of the stria terminalis; CeA, central nucleus of the amygdala; CoA, cortical nucleus of the amygdala; DMH, dorsomedial hypothalamus; GP, globus pallidus; MA, medial nucleus of the amygdala; PAG, periaqueductal gray; PVN, paraventricular nucleus of the hypothalamus; RN, raphe nuclei; SN, substantia nigra; VTA, ventral tegmental area. (B) Although CRHR1 activation leads to CAMP rise, the time course of this response and the effectors activated downstream vary according to the cell context. The CAMP response can either be sustained (hippocampal neurons and fibroblast-derived cell lines) or transient (corticotroph cells) and it is only linked to ERK1/2 activation in neuroendocrine or neuronal contexts (hippocampal neurons and corticotroph cells).

http://www.endocrineconnections.org DOI: 10.1530/EC-17-0111 (c) 2017 The authors Published by Bioscientifica Ltd

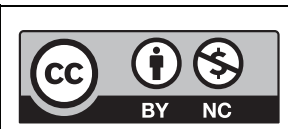

This work is licensed under a Creative Commons Attribution-NonCommercial 4.0 International License. 
of norepinephrine release, mainly at the locus coeruleus (LC), is considered to underlie the emotional bases of the stress response (22).

The negative feedback exerted by glucocorticoids inhibits ACTH and CRH release at the pituitary and hypothalamus, respectively. This critical feature of the HPA axis is lost in ACTH-secreting adenomas (23) and in some depressed patients (24), creating a hypercortisolemic state. However, in extrahypothalamic circuits, as in the central nucleus of the amygdala (CeA), glucocorticoids action stimulates rather than inhibit CRH synthesis (see (25) for references).

$\mathrm{CRH}$ and UCNs are known to regulate neuronal excitability by modulating ionic currents. CRH-activated CRHR1 was found to increase neuronal excitability of hippocampal CA1 pyramidal neurons through a mechanism dependent on L- and T-type calcium channels and voltage-gated potassium channels but independent on intracellular calcium rise (26). CRH excitatory action was also described in the LC, where cAMP/PKA-dependent phosphorylation of potassium channels led to a decrease in potassium conductance (27). Regarding CRH-like peptides, UCN2 reduced intracellular calcium levels by inhibiting L-type channels in undifferentiated PC12 cells (28). In MN9D dopaminergic cells, UCN1 activates CRHR1 and modulates T-type calcium channels in a PKCdependent manner (29), whereas in HEK293 cells, both UCNs and CRH acting via CRHR1 selectively inhibit CaV3.2 T-type calcium currents (30).

As expected from the intricate neuronal circuits that are interconnected to generate different outputs depending on the brain area and neurotransmitterspecific neurons involved, a variety of effects of CRH are observed, although most of the mechanistic aspects of these interactions in the brain are not defined yet (31). On the other hand, evidence obtained at molecular level in cell biology approaches, which may be meaningful to understand the outcome of combined effects, are not correlated by neurochemical studies or behavioral analysis. Integrated molecular cell biology studies and neurobiological approaches in animal models will be required to unravel the complex physiology of spatially convergent systems of the brain.

\section{Structural and functional features of CRH and urocortins and their receptors}

Phylogenetic studies showed that the origin of $\mathrm{CRH}$ and its related peptides predates the evolution of tetrapods and teleosts, strongly suggesting their essential role to maintain homeostasis (32). Two additional CRH-related peptides, urotensin I and sauvagine, have been isolated from fish and amphibians, respectively (33).

Although CRH was initially described for its function as a HPA regulator, CRH is widely expressed in central circuits (Fig. 2A) and also in peripheral tissues including heart, blood vessels, skin, lung, spleen, pancreas, kidney, liver, adipose tissue, digestive tract, testes, ovaries and placenta (9). The expression of urocortins (UCNs) in the brain is more restricted than that of $\mathrm{CRH}$, being also found in pituitary, heart and vasculature, skeletal muscle, kidney, adipose tissue, digestive tract and gonads (34).

CRH and UCNs act through two receptors, CRHR1 and CRHR2, which belong to the class B family of GPCRs (Fig. 1C). CRHR1 and CRHR2 are encoded by different genes but present a 70\% identity at the amino acid level, with the major divergence found in their amino-terminal domains involved in ligand binding, and therefore, responsible for their agonist selectivity (33). The amino acid sequences of the intracellular and transmembrane domains of CRHRs present 80-85\% identity.

Several splice variants of CRHR1 have been identified but only one, CRHR $1 \alpha$, presents biological activity and is predominantly expressed. In humans, CRHR2 exists in three splice variants CRHR $2 \alpha, \beta$ and $\gamma$ (in mice only two isoforms are found) that differ in the amino-terminal domain and their tissue distribution $(2,9,33)$. CRHR $2 \alpha$ is the most abundant splice variant in the brain; CRHR2 $\beta$ is found almost exclusively in peripheral tissues such as retina, ovaries, testes, digestive tract, heart, skeletal muscle, lung and skin, whereas CRHR2 $\gamma$ is found in septum, hippocampus, amygdala, midbrain, frontal cortex and limbic regions of the human brain, but its function is still unknown $(9,10)$. The expression and distribution of CRHRs, CRH and UCNs in the different brain regions have been extensively reviewed recently (20).

Recent studies demonstrated that different ligands acting on the same receptor are determinants of specific cellular responses. Counteracting effects of CRH and UCN2 on stress effect in physiologically relevant responses have been described (35). At the molecular level, a novel mechanism by which the endosomal peptidase ECE-1, differentially regulates signaling of CRH and UCN1 has been recently reported (36).

CRH-binding protein (CRH-BP) is a $37-\mathrm{kDa}$ secreted glycoprotein, structurally unrelated to the CRHRs, that binds CRH and UCN1 with high affinity (37). CRH-BP is found in the liver, placenta and in circulation and http://www.endocrineconnections.org DOI: 10.1530/EC-17-0111
() 2017 The authors Published by Bioscientifica Ltd
This work is licensed under a Creative Commons Attribution-NonCommercial 4.0 International License. 
co-localized with CRH in some areas of the brain, including cerebral cortex and subcortical limbic regions $(2,38)$. Slightly higher plasma levels of CRH-BP have been reported in females (39). The role of CRH-BP is still not fully understood, and different functions have been proposed: to act as a decoy sequestering CRH and UCN1 to modulate CRHRs activation, but also to act independently of CRH (38) or to function as an escort protein for CRHR2 $\alpha$ localization (40).

\section{Structural characterization of CRH receptors}

GPCRs are the largest family of membrane proteins in the human proteome, mediate a myriad of cellular responses through interactions with a huge variety of extracellular molecules and are major targets for drug development. GPCRs share a common transmembrane topology and are classified into four major families: A (rhodopsin), B (secretin), C (metabotropic glutamate) and frizzled (41). Class B is the second largest class and consists of 15 GPCRs that bind physiologically relevant peptides. Structurally, class B GPCRs are characterized by a large extracellular amino-terminal domain (ECD) with a similar tertiary structure composed of three-layered $\alpha-\beta-\beta \alpha$ fold ('sushi domain'), stabilized by three conserved disulfide bridges, which are part of the binding site for ligand recognition (42) (Fig. 1C).

The 'two-domain' model is the accepted mechanism of ligand interaction with class B GPCRs: the carboxyl end of the peptide agonist binds primarily to the ECD and the amino portion interacts with the juxtamembrane domain, stabilizing the active conformation state of the receptor (42). The high-resolution structure of the ECD has been solved for CRHR1, CRHR2 $\alpha$ and CRHR2 $\beta$ bound to ligands $(43,44,45,46)$ providing information on ligand recognition and selectivity. The ECDs of the three receptors present a similar fold, being the aminoterminal $\alpha$-helix shorter in CRHR1 with respect to others. In addition, the mature CRHR $2 \alpha$ contains a non-cleavable pseudo-signal peptide that forms a hydrophobic $\alpha$-helix in the amino-terminus $(46,47)$. CRHR2 $\alpha$ was the first GPCR described with a pseudo-signal peptide (47), which generates specific signal transduction mechanisms, trafficking and internalization processes $(48,49)$ (Fig. 1C).

A mechanism of compatibility in the amino portion of receptors is sufficient for ligand binding recognition and discrimination among the family of $\mathrm{CRH}$ peptides $(44,46)$. Mutagenesis studies of the extracellular loops of CRHR1 showed that the juxtamembrane domain is also involved in ligand binding and receptor activation (50).
CRHR1 was the first class B GPCR reported to be able to form homo-oligomers at the plasma membrane and in intracellular compartments (51). CRHR2 $\beta$ also forms oligomers, but CRHR2 $\alpha$ behaves as a monomer as a consequence of the pseudo-signal peptide presence in the mature receptor, which is also believed to cause higher intracellular CRHR2 $\alpha$ localization and reduced levels in the cell surface (51). Moreover, it was proposed that the monomer/dimer state influences $G$ protein selectivity, whereas CRHR1 exhibited a bell-shaped concentrationresponse curve for cAMP, suggesting coupling to Gs and Gi; CRHR $2 \alpha$ or monomeric CRHR1 showed a monophasic concentration-response cAMP curve (48). Analyses of functional consequences of CRHRs homo-oligomers in physiological contexts await to be addressed.

The formation of heteromers of CRHRs with other GPCRs have been proposed to govern the integration of different signal transduction systems in complex biological responses, such as HPA activation, anxiogenic behavior and drug abuse. CRH effect at the pituitary level is amplified by arginine vasopressin (AVP), which is produced in the supraoptic nucleus and PVN, co-expressed and co-secreted from hypothalamic CRH neurons $(52,53)$. Both CRH and AVP neurohormones trigger different signaling pathways in pituitary corticotrophs, but the cellular mechanism underlying the synergistic effect of CRH and AVP on ACTH release is not completely understood. In mammals, the physiological actions of AVP are mediated by three class A GPCRs - V1a, V1b and V2 (54). V1bR is coupled mainly to the phospholipase C (PLC), which increases intracellular calcium and protein kinase $C$ (PKC) activity in corticotrophs. A crosstalk between AVP and CRH at the level of diacylglycerol and IP3 production by the V1bR and the accumulation of cAMP by the CRHR1 receptor could account, at least in part, for the synergism (55). In avian species, the homologous nonapeptide of mammalian AVP is arginine vasotocin. Four vasotocin receptors - VT1, VT2, VT3 and VT4 - have been identified. Of the four receptors, the VT2R appears to be involved in the stress response of birds (56). Recently, a direct allosteric interaction between vasopressin/vasotocin receptors and CRHR1 was proposed, based on FRET and bioluminescence resonance energy transfer (BRET) experiments with co-expressed receptors in different cellular systems. Although these studies involve expression of fluorescently tagged receptors in vitro, involvement of hetero-dimerization as a mechanism to explain CRH potentiation by AVP is attractive $(57,58,59)$.

$\mathrm{CRH}$ modulatory effect in dopamine circuits in the ventral tegmental area, which are linked to addiction http://www.endocrineconnections.org DOI: 10.1530/EC-17-0111
() 2017 The authors Published by Bioscientifica Ltd
This work is licensed under a Creative Commons Attribution-NonCommercial 4.0 International License. 
behavior, has been found to be dependent on CRHR1 activation of the PLC, PKC and PKA signaling pathways $(60,61)$. The ability of CRHR $2 \alpha$ and dopamine receptor 1 (D1R) to physically interact in HEK293T cells may be a molecular evidence of a concerted physiological action of CRH and dopamine in neurons (62). Oligomerization of CRHR1 and orexin1 receptor may provide support for pharmacologically significant interactions between CRH and orexin-A on dopamine release modulation (63).

CRHRs differ in their carboxyl termini, being a PDZ-binding motif (class I, STAV) present in CRHR1 but not in CRHR2 (64), although the cassette TAAV on CRHR2 carboxyl terminus was found to regulate CRHR2 internalization in HEK293 cells (65) (Fig. 1C). Membrane-associated guanylate kinases (MAGUKs) are a family of synaptic PDZ proteins that have been reported to interact with CRHR1 and regulate receptor trafficking $(66,67)$. The PDZ domain of CRHR1 allowed crosstalk with others receptors, such as 5HT2A serotonin receptor (64), suggesting that this motif also plays a role in the regulation of the biological response. Evidence on CRHR1 and serotonin -5-hydroxytryptamine (5-HT)system interactions have been obtained in terms of both molecular and behavioral effects. Enhanced serotonin signaling by $\mathrm{CRH}$ was shown to require $\mathrm{CRH}$-stimulated CRHR1 endocytosis and rapid recycling from endosomes, which resulted in increased cell surface expression of serotonin receptor (5-HT2R), in both HEK293 cells and mouse cortical neurons (64). Using pharmacological and optogenetic tools, a recent study described a circuit controlling fear and anxiety which was dependent on 5-HT from the dorsal raphe nucleus acting on CRHR1positive neurons of the extended amygdala (68).

The report of the first two class B GPCR crystal structures, CRHR1 (69) and glucagon receptor (GCGR) (70), represented a major advance in GPCR biology considering the therapeutic potential of this class of receptors. A thermostabilized transmembrane region of CRHR1 was crystallized in complex with a small-molecule antagonist that binds deep into the structure. Unlike class A GPCRs, CRHR1 and GCGR use distinct determinants for conformational control and their transmembrane domains adopt a pronounced V-shape, presenting a wider and deeper extracellular cavity that presumably forms the peptide-binding site (Fig. 1C). The openness of the receptor core somehow explains the previous difficulties in identifying small-molecule ligands. The solved structures showed distinct subpockets that could represent important sites for structure-based drug design and the possibility to generate biased agonism to regulate the physiological responses (71). The recent structure of the full-length class B calcitonin receptor (CTR) in complex with peptide ligand and heterotrimeric Gs protein was a huge breakthrough, not only for the additional knowledge provided but also because it is the first GCPR resolved by phase-plate cryo-electron microscopy (72). Important questions about the dynamics of the activation mechanism of class B GPCRs still remain largely unexplored, but these recent studies may open new avenues for rational design of novel ligands with therapeutic potential for this class of receptors.

\section{Signaling pathways engaged by CRHRs: more complex than initially thought}

The canonical GPCRs signaling mechanism is the coupling of ligand binding, which stabilizes an active conformation of the receptor, to the activation of the cytoplasmatic G protein heterotrimer through the exchange of GDP for GTP and the functional dissociation into $G \alpha-G T P$ and $G \beta \gamma$ subunits $(73,74)$. The separated $G \alpha-$ GTP and G $\beta \gamma$ subunits regulate the activity of different downstream effector proteins. The activated GPCRs are substrate of kinase phosphorylation and binding to $\beta$-arrestins, events that inhibit interaction with $\mathrm{G}$ proteins and promote endocytosis of receptors via clathrin-coated pits (CCPs). The Gs heterotrimer reassembles following the hydrolysis of GTP to GDP in the $\alpha$ subunit. Thus, acute GPCR signaling was assumed to be restricted to the plasma membrane. However, this traditional view has been challenged by more recent observations and is being replaced by a much more complex signaling model for GPCRs and in particular for CRHRs (75, 76, 77). In the following sections, we review advances in the understanding of the molecular signaling cascades engaged by the activated CRHRs.

\section{G protein activation}

The physiological functions of CRHRs in the CNS and the periphery have been mainly associated to an increase in intracellular cAMP levels. This is consistent with a predominant coupling to Gs, the canonical signaling pathway for class B GPCRs (42). However, as observed for other members of this class, CRHRs are highly promiscuous and capable of activating multiple $G \alpha$ types (71). Studies in tissues with endogenous CRHRs or in recombinant cell lines $(78,79,80)$ have shown different $G$ protein coupling including Gs, Go, Gq/11, Gi1/2 and Gz. http://www.endocrineconnections.org DOI: 10.1530/EC-17-0111
(๔) 2017 The authors Published by Bioscientifica Ltd
This work is licensed under a Creative Commons Attribution-NonCommercial 4.0 International License. 
The characterization of the GPCR/G protein complex structure has been achieved for two class A GPCRs, rhodopsin and $\beta 2$ adrenergic receptor $(\beta 2 \mathrm{AR})(81,82,83)$, and recently for class B CTR (72). Activation mechanisms for most class B GPCRs have been explored by mutagenesis approaches to identify critical residues and motifs involved in the recognition and coupling to $\mathrm{G}$ proteins. For CRHR1, alaninescanning studies determined that the cationic $\alpha$-helices near TMD5 and 6 are crucial for this function and that the intracellular loop 3 (ICL3), the juxtamembrane regions as well as basic amino acids also contributed as recognition sites for Gs, Gi and Gq protein (84). It is remarkable that the ICL3 is $100 \%$ conserved in all the CRHRs discovered to date (9), highlighting its functional importance. Determinants of the carboxyl terminus also seem important for $G$ protein coupling $(72,78)$. Finally, the selectivity of $G$ proteins also depends on accessory proteins (49). Further exploration of $\mathrm{G}$ protein activation mechanisms by CRHRs is needed for a better understanding of the system.

\section{The cAMP response}

Most biological functions of CRH and UCNs, both in the CNS and the periphery, have been related to CRHRs ability to trigger cAMP production. Earl Sutherland and Ted Rall discovered adenosine 3', 5'-monophosphate (commonly referred as cyclic AMP or cAMP) in 1958 as a mediator of the function of the hormone adrenaline (85). It was rapidly recognized that cAMP mediated the action of several hormones and the concept of second messenger was introduced. In the words of Sutherland during the 1971 Nobel Prize winner speech for this revolutionary concept developed in the field of endocrinology 'cyclic $\mathrm{AMP}$ as a second messenger in hormone action, with the hormones themselves acting as first messengers' (86). The wide-ranging effects and variety of cell processes regulated by cAMP helped to generate great excitement around second messenger function. How is it possible that a single molecule mediates so many and often opposed physiological processes simultaneously? The existence of cAMP microdomains where cAMP is discretely and selectively regulated at the subcellular level to ensure the fine and precise actions of cAMP was proposed more than 30 years ago (87). Experimental support for this model required the development of live-cell sensors for cAMP that allowed spatial and temporal resolution with respect to traditional methods. The use of these techniques is changing our understanding of cAMP-dependent regulation, and in particular, of cAMP generation downstream GPCR activation.
Several studies demonstrated that CRHR1 and CRHR2 activation leads to a rapid accumulation of cAMP $(48,88$, 89). Using a cAMP biosensor based on Förster resonance energy transfer (FRET), the CRH elicited cAMP response in different physiologically relevant scenarios was recently explored (Fig. 2B). In the corticotroph-derived cell line AtT20, CRH led to a transient increase in cAMP levels (89). On the other hand, the cAMP response elicited by $\mathrm{CRH}$ in hippocampal and cortical primary cell cultures was sustained for at least $10 \mathrm{~min}$ after stimulation (90). Notably, the hippocampal neuronal cell line HT22 stably expressing CRHR1 (HT22-CRHR1) also showed a prolonged cAMP response, which stayed elevated for $40 \mathrm{~min}$ (89). CRH also triggered a sustained cAMP response in the fibroblastderived 3T3L1-CRHR1 cells (89), further suggesting that the dynamics of cAMP depend on the cellular context. No differences were observed in the CRHR1-regulated cAMP response when $\mathrm{CRH}$ or UCN1 were used as ligands in a hippocampal context (90).

The question about the diversity and specificity of cAMP-regulated processes can be at least in part answered by the existence of different adenylyl cyclases (ACs), with different expression profiles and regulatory properties. Accumulating evidence suggests that the ACs not only generate cAMP, but also orchestrate their own microenvironment by recruiting signaling components and scaffolding molecules, therefore, contributing to the temporal and spatial resolution of the signals (91). There are nine $G$ protein-regulated transmembrane ACs (tmACs), each with additional regulatory properties (92). A second type of AC is the soluble adenylyl cyclase (sAC), an evolutionarily conserved enzyme insensitive to $G$ protein regulation but directly activated by bicarbonate (93) and calcium ions $(94,95)$. sAC is localized throughout the cell, enabling the production of cAMP in different intracellular locations close to specific cAMP targets (96).

Perhaps the best-characterized role of sAC is during sperm capacitation in testis, but growing evidence indicates sAC is ubiquitously expressed and might be responsible for cAMP-mediated functions previously attributed to tmACs $(96,97,98,99)$. Although GPCRmediated cAMP production was thought only dependent on tmACs, the involvement of sAC in GPCR signaling has recently emerged $(97,100)$. The study of cAMP response elicited by CRH-activated CRHR1 demonstrated that both tmACs and sAC are involved in two physiologically relevant scenarios, hippocampal HT22-CRHR1 and neuroendocrine AtT20 cells (89). Moreover, different cAMP sources were found to be involved in different signaling mechanisms: tmACs and sAC were required

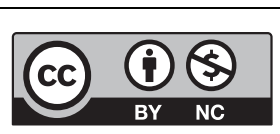

This work is licensed under a Creative Commons Attribution-NonCommercial 4.0 International License. 
for acute ERK1/2 activation but only sAC was critical for sustained phospho-ERK1/2 (89) or CRH-mediated neuritogenic effect in HT22-CRHR1 cells (90).

Notably, the participation of sAC depended on the GPCR identity (sAC was not engaged downstream $\beta A R s$ or PAC1 receptor) and the cellular context (sAC did not participate in CRHR1 signaling in fibroblast-derived 3T3L1-CRHR1 cells) suggesting that sAC is not a general mediator of GPCRs (89). Given that sAC activation depended on CRHR1-mediated calcium response (89), it will be important to further investigate the function of sAC considering it might be a key element integrating two essential second messengers, cAMP and calcium, especially in neurons $(101,102)$.

The existence of different cAMP effectors also contributes to cAMP-mediated response diversification. Many of the cellular functions regulated by CRH or UCNs have been attributed to protein kinase A activation (PKA) $(89,90,103,104,105)$. Phosphorylation of the transcription factor cAMP response element-binding protein (CREB) is essential for neuronal transcriptional programs in response to multiple external signals. Interestingly, CRH activates CREB in an ERK1/2independent, sAC- and tmACs-dependent mechanism in HT22-CRHR1 cells (90). After the identification of EPACs (exchange protein activated by cAMP), their activity has also been reported to mediate cAMP-dependent CRHR1 $(89,106)$ and CRHR2 (104) cellular responses. A plethora of signaling mechanisms is modulated by cAMP, but MAPK activation has received special attention in the context of CRH and UCNs function.

The development of biosensors capable of monitoring cAMP and cAMP effectors activity in live cells became valuable tools to understand the signaling mechanisms engaged by CRHRs that may contribute to the general comprehension of GPCRs function. Remarkably, these imaging techniques allow the real-time measurement of cAMP in live cells and in more physiological systems, such as brain slices. They can be combined with electrophysiological recordings to decipher the reports in the neurobiology of CRH with simultaneous molecular mechanism exploration.

\section{ERK1/2 activation}

The MAPKs cascades consist of a module of three kinases (MAPKKK-MAPKK-MAPK), activated by a great variety of signals. A major role of the MAPK ERK1/2 pathway has been recognized in CRHRs biological action. ERK1/2 is widely distributed in the brain and is considered a central regulator of the molecular processes involved in learning, memory, neuronal plasticity and also, during the response to stress (see (107) for references).

In AtT20 cells, the cAMP-dependent activation of ERK1/2 was critical for the expression of POMC, the ACTH precursor $(103,106)$. In addition, the in vivo intracerebroventricular CRH administration activated ERK1/2 in specific brain regions functionally involved in information processing and behavioral aspects of the stress response, such as hippocampus and basolateral amygdala (BLA, (108). The molecular mechanisms underlying ERK1/2 activation in a hippocampal neuronal context have been investigated, using HT22-CRHR1 cells as a cellular model. The temporal pattern of ERK1/2 phosphorylation in response to $\mathrm{CRH}$ was biphasic, with a first peak 3-6 min after stimulation and a second phase that remained activated for at least $60 \mathrm{~min}$ after CRH addition (105). Importantly, in this hippocampal context, ERK1/2 activation was dependent on cAMP levels in response to $\mathrm{CRH}(89,105)$ (Fig. 2B).

Considering that the MAPKKK B-Raf, main activator of the ERK1/2 pathway, also acts as a scaffold for assembling signaling complexes $(109,110)$, a proteomic analysis of B-Raf interactome was performed to unravel the cellular components potentially relevant for ERK1/2 pathway regulation in neurons (76). The role of a subset of B-Raf-interacting proteins mediating CRHR1 activation was evaluated (105). Using this approach, it was shown that at least two distinct mechanisms mediate ERK1/2 activation, one dependent on $G$ protein activation and a second regulated by CRHR1 internalization and $\beta$-arrestin2 (105). The observation of this biphasic ERK1/2 activation for several GPCRs has helped to establish a new paradigm in GPCR signaling, where signals are not exclusively mediated by $\mathrm{G}$ protein activation but also by G protein-independent pathways (111), as discussed in the next section.

In contrast to the stimulatory effect of cAMP on ERK1/2 pathway in neuroendocrine $(103,106)$ or neuronal systems $(89,105,112)$, there are contexts where an increase in cAMP is not linked or even inhibits ERK1/2 activation (113). In fibroblastic-derived cell lines, HEK293-expressing CRHRs $(65,104,114)$ and 3T3L1CRHR1 (89), myometrium and breast cancer $(114,115)$ ERK1/2 is activated in response to CRH and UCNs without cAMP involvement. In addition, even in cellular systems where cAMP regulates ERK1/2 phosphorylation, there are signaling cascades and $\mathrm{CRH}$ functions regulated by http://www.endocrineconnections.org DOI: 10.1530/EC-17-0111 (c) 2017 The authors Published by Bioscientifica Ltd
This work is licensed under a Creative Commons Attribution-NonCommercial 4.0 International License. 
cAMP that are independent of ERK1/2 (90), revealing the complexity of the signaling networks.

\section{Small G proteins}

Small G proteins are a superfamily of monomeric 20-30 kDa GTP-binding proteins that act as molecular switches, cycling between an active GTP-bound state and an inactive GDP-bound state. Its regulation relies on the balance between the activity of guanosine nucleotide exchange factors (GEFs) that facilitate the exchange of GDP for GTP and GTPase-activating proteins (GAPs), which increase the intrinsic rate of GTP hydrolysis. This superfamily can be classified into five subfamilies according to structure similarity and function: Ras, Rho, Arf, Rab and Ran family GTPases (116).

CRH-stimulated CRHR1 leads to the activation of two members of the Ras family (Ras and Rap1) and both proteins are part of the B-Raf complex responsible for ERK1/2 activation in a hippocampal neuronal context (105). Taking this into account, it would not be surprising to find other members of this superfamily or even modulators as binding partners of the MAPKKK B-Raf.

Among small GTPases, Rho family is involved in cytoskeletal organization and dynamics regulation, being a common effector of signaling mechanisms associated with cytoskeletal rearrangements and cell motility. Recent studies have shown that CRHR1 activation plays a role in neuronal architecture, but the exact nature of such modulation is still not clear due to controversial evidence. In the LC, this effect seems ligand dependent: CRH stimulates growth and arborization of LC neuronal processes, whereas UCN2 has an inhibitory effect (117). These opposing outcomes might be explained by the fact that each ligand triggers distinct signaling pathway downstream CRHR1. CRH action requires PKA, ERK1/2 and Rac1, whereas UCN2 effect is mediated by PKC and RhoA (117). CRH/CRHR1-mediated promotion of neurite outgrowth through PKA- and ERK1/2-dependent mechanisms has also been reported in the noradrenergic LC-like CATH.a cell line and Purkinje cells in cerebellar slices $(112,118)$. Reduced dendritic arborization of neurons of the developing hippocampus requires the same signaling cascade (119). The cell model used in each case may account for the variety of effects and actors involved in CRHR1-mediated cytoskeletal changes.

Stress impairs learning and memory via mechanisms that disrupt the integrity of hippocampal dendritic spines. Although $\mathrm{CRH}$ action on spine density and distribution seems to depend on the brain region analyzed, the regulation of RhoA activity is consistently involved as its consequent remodeling of actin cytoskeleton. These alterations in neuronal architecture generate changes in both the number and strength of synapses that could account for cognitive impairment associated with stress-related pathologies (120). Future studies regarding Rho GTPases involvement in CRH signaling need to be carried out at a molecular level to define CRH-triggered mechanisms regulating neuronal morphological changes.

\section{G $\beta \gamma$-mediated signaling}

Originally, it was thought that the $G \beta \gamma$ dimer was only necessary for the inactivation of $\mathrm{G} \alpha$ subunits given that it prevented spontaneous $G \alpha$ activation in the absence of receptor stimulation and allowed the interaction with the receptor for new cycles of signaling. Later on, reconstitution studies showed that $G \beta \gamma$ is required for GPCR-mediated nucleotide exchange (121). G $\beta \gamma$ binding to $G \alpha$ was either required to target $G \alpha$ to the membrane (122) or to organize $G \alpha$ subunit structure so that it could become a substrate for receptor interactions (121). However, it is now well established that G $\beta \gamma$ dimers can activate their own signaling pathways downstream of GPCRs. As they lack a catalytic site, G $\beta \gamma$ dimers are considered modulators of protein activity through the interaction with their effectors in sites known as hot spots (121).

Remarkably, G $\beta \gamma$-mediated MAPK activation has already been described in various systems. Using COS-7 cells as model, it was shown that G $\beta \gamma$ complex is involved in muscarinic receptor $1-$ and -2 mediated ERK1/2 and JNK activation as well as ERK1/2 activation downstream of $\beta 2 \mathrm{AR}$ (123). The use of dominant negative mutant forms of several Rho GTPases abolished G $\beta \gamma$ stimulatory action, suggesting that these proteins mediate the effects of $G \beta \gamma$ complex observed $(124,125)$. Little is known about $G \beta \gamma$ role in CRHR signaling. In HEK293 cells, G $\beta \gamma$ stimulated ERK1/2 phosphorylation in response to CRHR1 activation by UCN1 (126). There is also evidence of a stimulatory effect of $\mathrm{G} \beta \gamma$ regarding CRH/CRHR1-mediated CREB activation in primary cultures of striatal neurons and pyramidal neurons of the hippocampus $(127,128)$.

For GPCRs such as parathyroid hormone receptor (PTHR1) or $\beta 2$-adrenergic receptor ( $\beta 2 \mathrm{AR}$ ) the involvement of $\mathrm{G} \beta \gamma$ complex on signaling has been studied in detail $(129,130)$, leading to the discovery of non-canonical pathways regarding receptor transactivation and 
endosomal signaling/cAMP production. This opens a whole new scenario for GPCR signaling that is definitely worth addressing for the CRH system.

\section{CRHRs endocytosis: desensitization and signaling}

In the classical paradigm, agonist-activated $G$ proteinmediated signaling is terminated at the plasma membrane by a mechanism that involves receptor internalization. The phosphorylation of Ser/Thr residues of the cytoplasmic loops and tail of the GPCRs promotes the recruitment of $\beta$-arrestins, which destabilize the interactions with $G$ proteins and bind AP-2 and clathrin, causing the whole complex to be internalized. Thus, in this model, there is a temporal correlation between receptor internalization and the attenuation of the GPCR signaling (111). Although there is no doubt about the role of endocytosis mediating long-term signal extinction, numerous studies have helped building an new picture in which endocytosis modulates signaling, enabling cells to regulate the spatial and temporal control of the signal $(76,131)$.

Following agonist-induced activation, CRHRs undergo rapid endocytosis, reducing the number of receptors present on the cell surface and diminishing the cellular responsiveness to the extracellular ligand. Due to the lack of reliable antibodies to detect endogenous expression of CRHRs (132), kinetics of receptor endocytosis have been mainly studied in cell models transfected with tagged forms of the receptors. In HT22-CRHR1 cells, a significant fraction of CRH-activated CRHR1 was internalized after $5 \mathrm{~min}$ of stimulation and remained constant for at least $30 \mathrm{~min}$ (89). Similar results were observed in HEK293-CRHR1 cells and cortical neurons after $10 \mathrm{~min}$ of $\mathrm{CRH}$ addition. Internalized CRHR1 was found to be accumulated in intracellular clusters $(89,105,133)$. Regulated endocytosis of CRHR2 $\alpha$ (134) and CRHR2 $\beta$ (65) has also been reported.

After receptor activation, desensitization mechanisms have been extensively reported in line with the physiological notion that high ligand levels promote the attenuation of the response. This process has been described in cell lines overexpressing recombinant CRHRs, human myometrial cells, rat pituitary, human retinoblastoma and neuroblastoma cell lines Y79 and IMR32 (see (9) for references). Desensitization was also found dependent on specific ligands activating CRHRs (135). CRH and UCN1 differential regulation of CRHR1 recycling and resensitization has been recently demonstrated to be dependent on the endosomal peptidase ECE-1 (36).

The mechanism of desensitization has received special attention considering that the failure of this signal regulation during recurrent exposure to stress may be causally related to pathological conditions (20) or the sex differences observed in the receptor rate of internalization could explain the increased vulnerability of females to stress-related disorders (136). Sex-dependent mechanisms have also been described in CRHR2 and UCN1-mediated stress-mediated inflammation responses $(137,138)$.

Phosphorylation of the cytoplasmic loops and tail of the activated GPCRs is catalyzed predominantly by G protein-coupled receptor kinases (GRKs) (139, 140). CRHR1 phosphorylation involved in desensitization was reported to be mediated by GRK3 and GRK6 in HEK293 (88) and GRK3 in Y79 neuroblastoma cells (141), while in AtT20 cell line GRK2 was the main kinase involved (142). Notably, the kinetics of signal desensitization and recovery depended on the cell system studied. CRHR1 endogenously expressed in AtT20 corticotrophs (143) or recombinantly overexpressed in HEK293 cells resensitize within 1-2 h after CRH stimulation (88). However, a full recovery of the response was achieved only after $24 \mathrm{~h}$ post CRH addition in neuroblastoma IMR-32 or retinoblastoma Y79 cells $(144,145)$. Although trafficking and degradation rates of CRHRs may depend on the analyzed systems, these differences might also be explained by a differential expression of GRKs and arrestins in different cell types (146). Therefore, relative expression of modulators of GPCR internalization may influence CRHRs activity in physiological contexts of CRH action.

\section{$\beta$-arrestins: GPCR internalization and organizers of signaling complexes}

Arrestins were originally recognized for their ability to bind the activated GPCR and 'arrest' signaling via G proteins. However, over the years, it has been appreciated that arrestins not only prevent $G$ protein activation but also have the capacity to function as multifunctional adaptor proteins that modulate endocytosis and transduce signals to multiple effector pathways $(147,148)$. Arrestins critically regulate GPCR desensitization: they are recruited to phosphorylated GPCRs and initiate internalization by linking the receptor to the adaptor protein subunits of CCPs. Remarkably, arrestins also serve as scaffolds of a diverse group of signaling mediators, such as MAPKs, nuclear factor- $\mathrm{kB}(\mathrm{NF}-\kappa \mathrm{B})$ and phosphoinositide 3-kinase http://www.endocrineconnections.org DOI: 10.1530/EC-17-0111
() 2017 The authors Published by Bioscientifica Ltd
This work is licensed under a Creative Commons Attribution-NonCommercial 4.0 International License. 
(PI3K) $(111,149,150)$. The dual role of $\beta$-arrestins as attenuators and also as propagators of the signal changed the relatively simple previous model of GPCR signaling involving $G$ protein activation followed by endocytosisdependent desensitization.

Several studies have shown that CRHRs activation promotes a rapid recruitment of $\beta$-arrestins to the plasma membrane and this favors receptor internalization $(65,88,133,146,151)$. The relative contribution of $\beta$-arrestin- 1 and $\beta$-arrestin- 2 in CRHR1 internalization has been investigated. Ligand-activated CRHR1 binds to both $\beta$-arrestins (146) but preferentially to $\beta$-arrestin- 2 in HEK293, CHO-K1 cells and in primary cortical neurons transfected with CRHR1 $(133,143,146)$. It has also been shown that CRHR2 $\alpha$ (134) and CRHR2 $\beta$ (65) preferentially recruit $\beta$-arrestin- 2 once activated.

In line with $\beta$-arrestin dependence of agonist-induced CRHR1 endocytosis, inhibition of $\beta$-arrestin function diminished (88), whereas $\beta$-arrestin overexpression augmented (146) CRHR1 internalization. Although both GRKs and $\beta$-arrestins play important roles regulating CRHR1 desensitization, $\beta$-arrestin binding seem to be mediated by both phosphorylation-dependent and -independent motifs $(146,151)$ suggesting the existence of complex regulatory mechanisms of receptor internalization. Sex differences in $\beta$-arrestin- 2 recruitment to CRHR1 have been observed (152). In LC neurons, the level of association between $\beta$-arrestin- 2 and CRHR1 under unstressed conditions was comparable in males and females, but stress exposure only induced $\beta$-arrestin- 2 recruitment and subsequent CRHR1 internalization in males. In addition, there was an enhanced coupling to Gs of CRHR1 in female neurons suggesting a model of sex-biased signaling. The sex differences in receptor association with $G$ proteins and $\beta$-arrestin-2 do not depend on circulating gonadal hormones but may arise from posttranslational modifications. These gender differences in CRHR1 signaling and trafficking suggest a deficient adaptation to excessive exposure to CRH in females, which may contribute to the increased incidence of stress-related psychiatric diseases in females (136).

The finding of non-canonical GPCR signaling pathways mediated by $\beta$-arrestins has represented a true paradigm shift. Moreover, the biochemical data suggesting that cascades activated by $\beta$-arrestins may have distinct physiological outcomes from those activated by $\mathrm{G}$ proteins have led to great pharmacological efforts in developing biased agonists, which selectively activate specific signaling pathways given their therapeutic potential (111).
By inhibiting $\beta$-arrestin function, it was shown that CRHR1 activates ERK1/2 in a mechanism dependent on $\beta$-arrestin2 in HT22-CRHR1 cells (105). Interestingly, the $\beta$-arrestin-dependent ERK1/2 phosphorylation had different temporal characteristics with respect to the early ERK1/2 activation mediated by $G$ proteins. The sustained $\beta$-arrestin-mediated phospho-ERK1/2 is observed after $20 \mathrm{~min}$ of ligand addition. Moreover, the late ERK1/2 activation phase was also dependent on CRHR1 internalization, suggesting that $\beta$-arrestin functioning as a signaling scaffold is linked to its role in regulating receptor internalization (105).

The activation of the MAPK cascade was the first pathway to be described dependent on $\beta$-arrestin function downstream an activated GPCR $(149,153)$. It is proposed that $\beta$-arrestins function as scaffolds allowing the organization of signaling complexes. $\beta$-arrestin-mediated ERK1/2 phosphorylation is likely to be physiologically relevant as this ERK1/2 pool seems to have different consequences compared to the pool activated by $G$ proteins (154). It has been reported to play a role in chemotaxis and cytoskeletal rearrangements $(155,156)$ as well as in cardiac function (157).

The mechanistic basis of $\beta$-arrestin-mediated signaling has remained unclear for a long time. Recently, several studies have made important progress in the understanding of this process. It is now recognized that $\beta$-arrestins exist in a large array of conformations, are very dynamic and can interact with more partners that previously thought (158). Moreover, GPCRs can impose conformational signatures on $\beta$-arrestins and $\beta$-arrestins remain active following receptor dissociation (159). These findings addressed the previous contradictory observations of $\beta$-arrestin-mediated ERK1/2 activation stimulated by GPCRs that interact transiently with $\beta$-arrestins and do not co-localize in endosomes, such as CRHR1 and CRHR2, and even GPCRs that are poorly phosphorylated and weakly internalized, such as $\beta 1$-adrenergic receptors (160).

In addition to previously mentioned $G$ proteins, GRKs and $\beta$-arrestins, GPCRs interact with numerous proteins, including other GPCRs, GPCR accessory proteins and intracellular proteins, which modulate signaling, expression and pharmacological profiles of GPCRs. GPCR biosynthesis, trafficking to the cell surface, compartmentalization to specific membrane microdomains and endocytosis are processes regulated by accessory or escort proteins (161). Co-expression of receptor-activity-modifying protein RAMP2 and CRHR1 increased the presence of both proteins at the plasma 
membrane and changed the $G$ protein coupling profile, enhancing Gi, Gq and G12/13 binding (71). Many other accessory proteins have been reported to interact with and modulate GPCRs, including regulators of G protein signaling (RGS), calpain and 14-3-3 proteins (162). Understanding these additional layers of GPCR regulation may represent opportunities for drug development.

\section{Prolonged signaling}

\section{CRHR1 continues to signal after internalization}

It was assumed for a long time that the internalized GPCRs were unable to signal. This premise was built upon technical limitations as well as experimental evidences, i.e. the observation that $\beta$-arrestins sterically blocked $G$ protein binding to GPCRs. However, results accumulated over the past several years support the alternative hypothesis that signaling can be initiated from endosomes. The first evidence of GPCR signaling from endosomal compartments was in yeast, where the activation of the $\mathrm{G} \alpha$ protein subunit GPA1 in intracellular membranes promoted a late signaling phase of the GPCR Ste2p (163). Prolonged GPCR signaling in mammalian cells was suggested in three independent reports investigating the mechanisms activated by different receptors. It was shown that the activation of GPCRs for parathyroid hormone (PTH, (164) and thyroid-stimulating hormone (TSH, (165) produced a sustained cAMP response, poorly reversed after ligand removal and temporally overlapped with receptor endocytosis. The observation of the prolonged effect of the sphingosine-1-phosphate receptor (S1P1R) agonist, extended this model to the Gi-linked signaling (166). This prolonged signaling engaged by GPCRs was referred as non-canonical, considering that acute $G$ protein activation restricted to the plasma membrane was the classic signaling pathway. However, this persistent signaling has been subsequently reported for other GPCRs, including peptide hormone receptors, such as glucagonlike peptide 1 receptor (GLP1R) (167), pituitary adenylate cyclase activating polypeptide (PACAP) type 1 receptor (168), vasopressin receptor (V2R) (169) and monoamine receptors such as dopamine receptors (170) and $\beta 2 A R$ (171, 172). These recent evidences strongly suggest that this would be a general mechanism instead of an exception, and led to reevaluate the previous assumptions. A much more complex signaling mechanism engaged by GPCRs is emerging, where endosomes act as signaling platforms that allow spatial and temporal control of the signals originated at the plasma membrane and the fine tuning of the biological response (131).

The use of FRET-based biosensors to study CRHR1 signaling revealed that the duration of the cAMP response elicited by $\mathrm{CRH}$ depends on the cellular model of study (Fig. 2B). Although in AtT20 cells the cAMP response is transient (89), primary cortical and hippocampal neurons as well in HT22-CRHR1 cells show a more prolonged response $(89,90)$. The fact that in a hippocampal context, the time course of CRHR1 internalization overlapped that of cAMP production (89) and that endocytic blockade reduced the activation of cAMP-dependent signaling cascades, such as ERK1/2 (105), suggested that CRHR1 also continued to signal once internalized. By monitoring the cAMP response to $\mathrm{CRH}$ in live cells, it was shown that endocytosis blockade by inhibiting dynamin reduced cAMP levels (89). Interestingly, endocytosis inhibition did not affect the initial rise in cAMP levels, but the differences were significant at later time points, when receptor endocytosis was evident. Also, inhibition of dynamin did not alter cAMP production elicited by receptorindependent activation of ACs with forskolin, showing that receptor activation was necessary for this mechanism (89). Although CRH-activated CRHR1 stimulates a nearly simultaneous rise in intracellular calcium levels in addition to the cAMP increase, endocytosis did not regulate the calcium response (89).

Mechanisms of sustained GPCR signaling The findings of prolonged GPCR signaling support the existence of mechanisms that enable pathway activation from endosomal stations, different from those occurring at the plasma membrane. Using conformational biosensors based on single-chain antibodies or 'nanobodies', it has been demonstrated for $\beta 2 \mathrm{AR}$ that endosome-localized receptors are active and can engage new cycles of Gs activation (171).

Because $\beta$-arrestins binding to the transmembrane core of the receptor overlaps the binding site of $G$ proteins $(173,174,175)$ it was assumed that signaling pathways dependent on $G$ protein activation ended when the GPCR- $\beta$-arrestin interaction was formed. The mechanisms by which $G$ protein activation from endosomes occurs are only starting to be understood. For GPCRs that form transient complexes with $\beta$-arrestins two phases of $G$ protein activation were observed, the first at the plasma membrane and the second following receptor http://www.endocrineconnections.org DOI: 10.1530/EC-17-0111
() 2017 The authors Published by Bioscientifica Ltd
This work is licensed under a Creative Commons Attribution-NonCommercial 4.0 International License. 
internalization after the endocytic vesicle uncoating from $\beta$-arrestins and CCP-associated components (171).

These observations were more difficult to reconcile for those GPCRs that form stable complexes with arrestins and that internalize together into endocytic vesicles. Recently, it has been observed that $\beta$-arrestins also assume a 'tail' conformation, in which they are only bound to the carboxyl-terminal tail of the receptor (173) allowing the GPCR to interact simultaneously with both Gs and $\beta$-arrestins (176). These results have provided a molecular basis for sustained $G$ protein signaling from endosomes.

Studies on GPCRs for which $\beta$-arrestins promote rather than attenuate cAMP production, such as PTHR and V2R, have also contributed to our current understanding of the molecular events involved in regulating GPCR signaling after receptor internalization. A particular receptor conformation is needed to maintain Gs signaling from endocytic vesicles. This active conformation is achieved when PTH is the ligand, but there is a different active conformation stabilized by PTHrP that mediate more transient responses $(75,164)$. It has been proposed that cAMP generation by PTH-activated PTHR1 is maintained in early endosomes by a positive feedback mechanism, where arrestin-dependent activation of ERK1/2 inhibits phosphodiesterases (PDEs) and favors the cAMP response (177). In addition, the formation of PTHR1- $\beta$-arrestin-G $\beta \gamma$ complexes might promote new cycles of Gs activation and prolong cAMP signaling (129). $\beta$-arrestins also promoted a sustained cAMP generation in response to vasopressinactivated V2R, a class A GCPR (169). Again, these results challenge the classical role of $\beta$-arrestins in desensitization of GPCRs, showing that they might promote specific signaling mechanisms.

For CRHR1, the study of the molecular mechanisms engaged by different cAMP sources led to the characterization of an alternative mechanism for endosome-based GPCR signaling (Fig. 3). In response to $\mathrm{CRH}$, the endocytosis-dependent cAMP generation and ERK1/2 activation critically depend on sAC activity. cAMP produced by both tmACs and sAC is required for the early phase of ERK1/2 phosphorylation triggered by CRHstimulated CRHR1, but only sAC activity is essential for the sustained internalization-dependent phase in HT22CRHR1 cells (89). Thus, the existence of different ACs, with specific regulatory properties and subcellular distribution create a new layer of complexity. These results show that, at least in the case of CRHR1, the spatial resolution of the signals is achieved by the involvement of an alternative source of cAMP instead of just by the formation of specific signaling complexes along the endocytic pathway (178).

The fact that the endocytosis-regulated ERK1/2 phosphorylation also depends on $\beta$-arrestin2 (105) raises the question of whether $\beta$-arrestins are also involved in cAMP generation from endosomes in response to $\mathrm{CRH}$, and if sAC and $\beta$-arrestin are functionally connected. It is interesting that the endocytosis-dependent component of the cAMP production in response to CRH was not affected by ERK1/2 pathway inhibition (89), different to what was observed for PTHR1 (177). This suggests that the activation of signaling pathways from endosomes might occur through a variety of mechanisms that coexist or that are differentially involved depending on the GPCR or the cellular context.

\section{Future questions: significance of endosomal signaling}

The recent results presented here reveal new aspects of CRHRs signaling mechanisms that are only beginning to be explored. In the light of an emerging view of GPCR function many important questions await to be addressed.

If the CRHR1 continues to signal once internalized, which mechanisms are involved in signal termination? Recent work suggests that mechanisms that regulate the post-endocytic fate of GPCRs are crucial $(76,77,179)$. Once endocyted, receptors enter a dynamic and elaborated tubulovesicular endosomal network where protein processing and sorting occurs. In general, following signal termination the inactive receptor can be directed to the lysosome for degradation or to recycling systems either directly to the plasma membrane or via the trans-Golgi network (TGN) (131).

The superfamily of Rab GTPases regulate various steps of membrane trafficking, being involved in targeting, tethering and docking of endosomal vesicles. Rab proteins have been demonstrated to modulate intracellular trafficking of GPCRs (see (180) for references). The endosome-based cAMP generation by PTHR1 has been localized in Rab5 early endosomes (164). Moreover, the signal turn off coincides with the release of $\beta$-arrestins and the engagement of the cargo-sorting retromer complex, which regulates protein sorting from early endosomes to the TGN (177). A negative feedback mechanism that includes PKA-regulated v-ATPase-mediated endosomal acidification is critical for shifting active PTHR1-arrestin to inactive PTHR1-retromer complexes (181). A key role of the retromer complex was also described for the http://www.endocrineconnections.org DOI: 10.1530/EC-17-0111
() 2017 The authors Published by Bioscientifica Ltd
This work is licensed under a Creative Commons Attribution-NonCommercial 4.0 International License. 
Classical signaling model

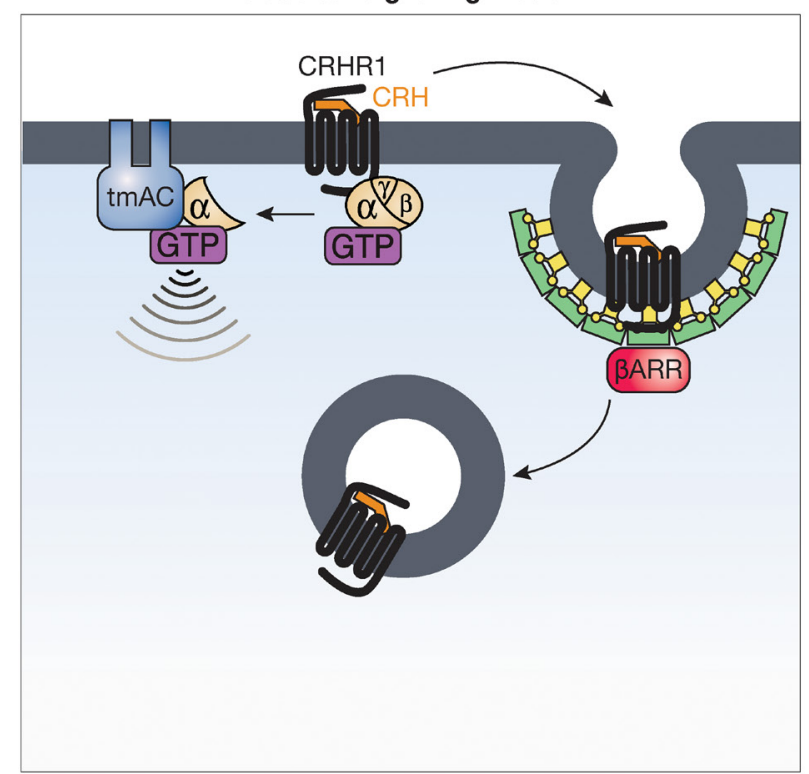

\section{Emerging signaling model}

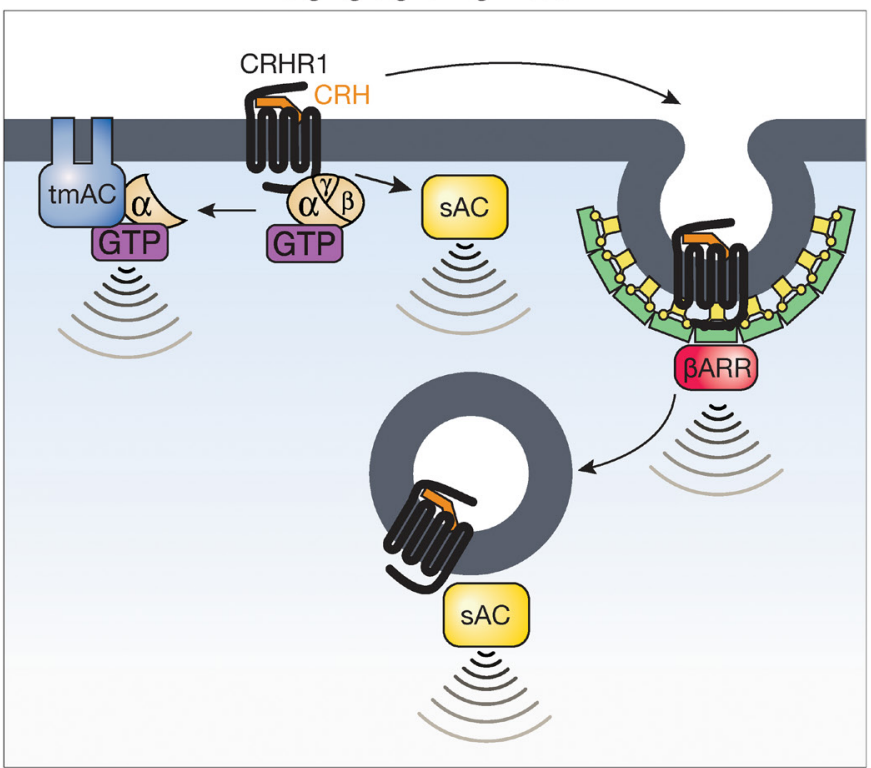

\section{Figure 3}

A new mechanism of CRH-activated CRHR1 signaling. In the classical model, CRHR1 activation by CRH is followed by a rise in cAMP mediated by G protein-dependent tmACs. Binding of $\beta$-arrestin2 to agonist-activated CRHR1 triggers receptor internalization leading to termination of agonistactivated G protein-mediated signaling. In the emerging model discussed in this work, an atypical pool of cyclic AMP is generated by soluble adenylyl cyclase (sAC) in response to CRHR1 activation in addition to cAMP generated by tmACs. In hippocampal neuronal cells cAMP was found to activate specific signaling pathways that are dependent on the source (tmACs or SAC) and cellular location (cell surface or endosomes) of the cAMP generation. In particular, SAC was critical for endosome-generated CAMP in response to $\mathrm{CRH}$.

termination of the endosomal signaling from V2R (169). In the case of $\beta 2 \mathrm{AR}$, it was recently shown that signaling from endosomes occurs exclusively in recycling tubules, pointing out again to the existence of mechanisms that allow spatial control of the signal (179). Internalization of activated CRHR1 in Rab5-positive early endosomes in HEK293 cells and in cortical neurons has been reported (133, 182), but simultaneous presence of CRHR1 and $\beta$-arrestins in endocytic compartments depended on the cell type (133). The nature of the intracellular domains that activated CRHR1 transits once internalized, with or without signaling proteins, needs to be determined in neuroendocrine and hippocampal neuronal contexts to define the mechanisms of both acute and sustained $\mathrm{CRH}$ signaling. The involvement of negative feedback mechanisms and/or molecular components of the retromer in signal termination need to be assessed for CRHR1.

How sAC is integrated in signaling complexes that allow the spatial information to be decoded is an important issue not explored yet. For example, whether sAC forms a physical complex with CRHR1 or an 'activation at a distance' mechanism is involved, as recently described for $\beta$-arrestins and $\beta 1 \mathrm{AR}$ (160), is still an open question. Recently, sAC was found associated with the A-kinase anchoring protein ezrin (183) and involved in specific functions in different subcellular localizations (96). There is a growing appreciation that ACs play a critical role not only as producers of cAMP but as true organizers of signaling complexes, mediating specific cellular functions as a core of highly organized microdomains (91).

Using a combination of BRET assay and single particle electron microscopy analysis, the formation of endosomal 'megaplexes' composed of $\beta 2 \mathrm{AR}, \beta$-arrestin, and heterotrimeric $\mathrm{G}$ protein has been shown (176). New BRET biosensors targeted either to plasma membrane or endosomes have been recently designed (184). The use of the latest high-resolution technologies will certainly have a strong impact on the study of GPCR signaling complexes at structural level.

Which is the functional significance of the endosomebased CRHR1 signaling? Are endosome-based signals functionally distinct from those initiated from the plasma membrane or do endosome-based events represent a spatial and/or temporal extension of a signal that is otherwise identical to that initiated at the cell surface? Recent evidences obtained for GPCRs suggest two main effects of the signals initiated in endosomes. First, it has been observed that the activation from endosomes extends the duration of the responses. It has been shown that the timing of the signal regulates physiological processes $(164,165,185)$ but the

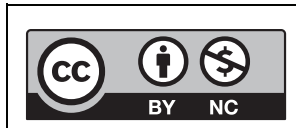

This work is licensed under a Creative Commons Attribution-NonCommercial 4.0 International License. 
specific roles of this pathway remain to be studied. Second, the endosome-based activation seems to provide a spatial specificity to downstream signaling mechanisms activated. For example, the location of the cAMP production controls the repertoire of target genes transcriptionally activated in response to $\beta 2 \mathrm{AR}$ activation (172).

Future studies should also address whether the two mechanisms of the biphasic ERK1/2 activation can account for different cellular processes. Despite the enthusiasm regarding the existence of mechanisms that may lead to different outcomes from activated GPCRs, whether they have any biological significance in native cell types or tissues is still an open question.

\section{Dysregulation of the CRH system}

Centrally released CRH plays a critical role in behavioral state of anxiety, independently of its effects on the pituitary (24). Overexpression of CRH induces stress and an anxiogenic-like phenotype in rodents (186), whereas suppressing $\mathrm{CRH}$ expression has anxiolytic effects in both basal and stress-induced anxiety (187). Genetic and pharmacological approaches have attributed $\mathrm{CRH}$ anxiogenic effects to the activation of CRHR1 (188, 189). In terms of abundance and distribution, CRHR1 is the main CRH receptor in the brain, whereas CRHR2 expression is more restricted (20). The role of CRHR2 activation mediating anxiety and depression has been less clear. Crhr2-knockout mice showed an anxiogenic phenotype, increased endocrine response, and impaired recovery after stress $(190,191)$ supporting a role of CRHR2 mediating stress recovery and the restoration of homeostasis. Similarly, deleting all three Ucn1-3 genes induced a susceptibility to the effects of stress exposure (192). A recent analysis in CRHR2 and UCN3 defective mice suggests that both are essential components of the CRH system to successfully cope with complex social challenges (193). It is to note that recent work using new neurobiological tools, such as conditional mutagenesis, viral manipulations and optogenetics, has allowed site-specific manipulation of CRHR1 and CRHR2 revealing a more complicated pattern of CRHRs responses in specific circuits of the brain, suggesting that both CRHR1 and CRHR2 modulate anxiety-like behavior in rodents in a brain region-dependent manner. Contrasting findings of effects of CRHR subtype activation are observed within single brain regions, implicating a highly complex mechanism of region dependency and circuit specificity, cell type and ligand involvement (20). In particular, the involvement of the limbic system (hippocampus and extended amygdala) has been the focus of many studies, given its central role in stressrelated behaviors, sensory processing of multimodal stimuli, learning and memory formation. The effects of stress on hippocampal structure and function are complex, and exhibit a bidirectional pattern depending on duration and intensity of the stimulus $(31,194)$.

In line with cell- and region-dependent effects, mice lacking CRHR1 in glutamatergic neurons show reduced anxiety and impaired neurotransmission in the hippocampus and BLA, whereas mice lacking CRHR1 in dopaminergic neurons show increased anxiety-like behavior and reduced dopamine release in the prefrontal cortex. This differential role for CRHR1 was suggested to indicate that, under physiological conditions, CRHR1controlled glutamatergic and dopaminergic systems might function in an antagonistic manner to maintain adaptive responses to stressful situations in balance (132, Fig. 2A). In that line, CRH effect on dopamine release in the nucleus accumbens was abolished in mice exposed to severe stress, which was accompanied by a depression-like phenotype evidenced as a shift of the CRH response from appetitive to aversive (195).

Clinical studies also support that stress-induced CRH actions are mediated through CRHR1 activation (196). Recent studies in humans revealed genetic and epigenetic variations in the CRH system that may be predictors of high vulnerability to neuropsychiatric stress-related disorders (197). Collectively, these evidences strengthen the notion of a critical function of the CRH system in stress-related pathologies, and highlight the need of a clear definition of molecular components and mechanisms involved in $\mathrm{CRH}$ signaling for designing new therapies.

\section{Perspectives: CRH signaling as a basis for discovery of drug targets}

The effects of stress on brain functions ranges from behavioral adaptation to enhance survival to increasing the risk to develop stress-related psychiatric disorders. A dysfunctional CRH system is associated with the occurrence of major depression, post-traumatic stress disorder, addiction behavior, and anxiety disorders $(7,198,199)$.

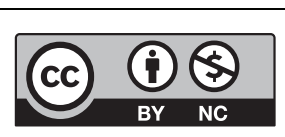

This work is licensed under a Creative Commons Attribution-NonCommercial 4.0 International License. 
Alteration of the CRH system and chronically elevated CRH levels are implicated in human stress-related affective disorders $(196,200)$. Augmented concentrations of CRH were found in cerebrospinal fluid from depressed (201) and post-traumatic stress disease (202) patients, and in some cases were normalized after antidepressant treatment $(203,204)$. Depressed suicide victims showed decreased levels of CRHR1 in specific brain areas, suggesting desensitization mechanisms due to excessive CRH (201, 205).

A number of psychiatric disorders, neurodegenerative diseases, behavioral and physiological manifestations of alcohol withdrawal, relapse to drug in addictions or compulsive eating in obesity -conditions that involve genetic predisposition and environmental stressors- have been linked to the activity of extrahypothalamic brain CRH systems (198). It has been suggested that high chronic stress and alterations in the CRH system are connected to the onset and development of neurodegenerative disorders, such as Alzheimer disease $(9,206)$. Therefore, a search for brain barrier penetrant small-molecule compounds to target CRHRs without causing metabolic and other side effects by HPA axis suppression is an area of active investigation (7). In numerous studies in animals and a few studies in humans, CRHR1 has been validated as a target modulated for antidepressants (6). However, clinical studies with CRHR1 antagonists in depressed subjects showed mixed results (52) which might be reflecting a need of a deeper understanding of CRHRs function to identify molecular targets with therapeutic potential.

As presented here, efforts to understand how CRHR1 exerts these important functions at molecular level have revealed new mechanisms of signaling that may be relevant in pathophysiological contexts (Fig. 3). A precise definition of CRH signaling mechanisms with spatial and temporal resolution will enable identification of novel targets for pharmacological intervention in neuroendocrine tissues and specific brain areas involved in CRH-related disorders.

\section{Declaration of interest}

The authors declare that there is no conflict of interest that could be perceived as prejudicing the impartiality of this review.

\section{Funding}

This work was supported by grants from the Agencia Nacional de Promoción Científica y Tecnológica (Max-Planck 13:0392), the University of Buenos Aires, the Consejo Nacional de Investigaciones Científicas y Técnicas, and the Fondo para la Convergencia Estructural del Mercosur (COF 03/11).

\section{References}

1 de Kloet ER, Joels M \& Holsboer F. Stress and the brain: from adaptation to disease. Nature Reviews: Neuroscience 20056 463-475. (doi:10.1038/nrn1683)

2 Bale TL \& Vale WW. CRF and CRF receptors: role in stress responsivity and other behaviors. Annual Review of Pharmacology and Toxicology 200444 525-557. (doi:10.1146/annurev. pharmtox.44.101802.121410)

3 Smith GW, Aubry JM, Dellu F, Contarino A, Bilezikjian LM, Gold LH, Chen R, Marchuk Y, Hauser C, Bentley CA, et al. Corticotropin releasing factor receptor 1-deficient mice display decreased anxiety, impaired stress response, and aberrant neuroendocrine development. Neuron 199820 1093-1102. (doi:10.1016/S0896-6273(00)80491-2)

4 Korosi A \& Baram TZ. The central corticotropin releasing factor system during development and adulthood. European Journal of Pharmacology 2008583 204-214. (doi:10.1016/j.ejphar.2007.11.066)

5 Maras PM \& Baram TZ. Sculpting the hippocampus from within: stress, spines, and CRH. Trends in Neurosciences 201235 315-324. (doi:10.1016/j.tins.2012.01.005)

6 Paez-Pereda M, Hausch F \& Holsboer F. Corticotropin releasing factor receptor antagonists for major depressive disorder. Expert Opinion on Investigational Drugs 201120 519-535. (doi:10.1517/13543784.2011.565330)

7 Sanders J \& Nemeroff C. The CRF system as a therapeutic target for neuropsychiatric disorders. Trends in Pharmacological Sciences 201637 1045-1054. (doi:10.1016/j.tips.2016.09.004)

8 Vale W, Spiess J, Rivier C \& Rivier J. Characterization of a 41-residue ovine hypothalamic peptide that stimulates secretion of corticotropin and beta-endorphin. Science 1981213 1394-1397. (doi:10.1126/science.6267699)

9 Hauger RL, Risbrough V, Brauns O \& Dautzenberg FM. Corticotropin releasing factor (CRF) receptor signaling in the central nervous system: new molecular targets. CNS and Neurological Disorders Drug Targets 20065 453-479. (doi:10.2174/187152706777950684)

10 Hillhouse EW \& Grammatopoulos DK. The molecular mechanisms underlying the regulation of the biological activity of corticotropinreleasing hormone receptors: implications for physiology and pathophysiology. Endocrine Reviews 200627 260-286. (doi:10.1210/ er.2005-0034)

11 Arzt E \& Holsboer F. CRF signaling: molecular specificity for drug targeting in the CNS. Trends in Pharmacological Sciences 200627 531-538. (doi:10.1016/j.tips.2006.08.007)

12 Sapolsky RM, Romero LM \& Munck AU. How do glucocorticoids influence stress responses? Integrating permissive, suppressive, stimulatory, and preparative actions. Endocrine Reviews 200021 55-89. (doi:10.1210/edrv.21.1.0389)

13 Herman JP, Figueiredo H, Mueller NK, Ulrich-Lai Y, Ostrander MM, Choi DC \& Cullinan WE. Central mechanisms of stress integration: hierarchical circuitry controlling hypothalamo-pituitaryadrenocortical responsiveness. Frontiers in Neuroendocrinology 200324 151-180. (doi:10.1016/j.yfrne.2003.07.001)

14 Quax RA, Manenschijn L, Koper JW, Hazes JM, Lamberts SW, van Rossum EF \& Feelders RA. Glucocorticoid sensitivity in health and disease. Nature Reviews: Endocrinology 20139 670-686. (doi:10.1038/nrendo.2013.183)

15 Britton DR, Koob GF, Rivier J \& Vale W. Intraventricula corticotropin-releasing factor enhances behavioral effects of novelty. Life Sciences 198231 363-367. (doi:10.1016/0024-3205(82)90416-7)

16 Sutton RE, Koob GF, Le Moal M, Rivier J \& Vale W. Corticotropin releasing factor produces behavioural activation in rats. Nature 1982 297 331-333. (doi:10.1038/297331a0)

17 Koob GF \& Bloom FE. Corticotropin-releasing factor and behavior. Federation Proceedings 198544 259-263.

18 Dunn AJ \& File SE. Corticotropin-releasing factor has an anxiogenic action in the social interaction test. Hormones and Behavior 198721 193-202. (doi:10.1016/0018-506X(87)90044-4)

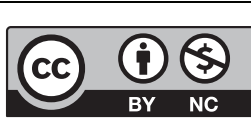

This work is licensed under a Creative Commons Attribution-NonCommercial 4.0 International License. 
19 Eaves M, Thatcher-Britton K, Rivier J, Vale W \& Koob GF. Effects of corticotropin releasing factor on locomotor activity in hypophysectomized rats. Peptides 19856 923-926. (doi:10.1016/0196-9781(85)90323-7)

20 Henckens MJ, Deussing JM \& Chen A. Region-specific roles of the corticotropin-releasing factor-urocortin system in stress. Nature Reviews: Neuroscience 201617 636-651. (doi:10.1038/nrn.2016.94)

21 Gallagher JP, Orozco-Cabal LF, Liu J \& Shinnick-Gallagher P. Synaptic physiology of central CRH system. European Journal of Pharmacology 2008583 215-225. (doi:10.1016/j.ejphar.2007.11.075)

22 Valentino RJ \& Van Bockstaele E. Convergent regulation of locus coeruleus activity as an adaptive response to stress. European Journal of Pharmacology 2008583 194-203. (doi:10.1016/j. ejphar.2007.11.062)

23 Perez-Castro C, Renner U, Haedo MR, Stalla GK \& Arzt E. Cellular and molecular specificity of pituitary gland physiology. Physiological Reviews 201292 1-38. (doi:10.1152/physrev.00003.2011)

24 Reul JM \& Holsboer F. Corticotropin-releasing factor receptors 1 and 2 in anxiety and depression. Current Opinion in Pharmacology 20022 23-33. (doi:10.1016/S1471-4892(01)00117-5)

25 Kovacs KJ. CRH: the link between hormonal-, metabolic- and behavioral responses to stress. Journal of Chemical Neuroanatomy 2013 54 25-33. (doi:10.1016/j.jchemneu.2013.05.003)

26 Kratzer S, Mattusch C, Metzger MW, Dedic N, Noll-Hussong M, Kafitz KW, Eder M, Deussing JM, Holsboer F, Kochs E, et al. Activation of CRH receptor type 1 expressed on glutamatergic neurons increases excitability of CA1 pyramidal neurons by the modulation of voltagegated ion channels. Frontiers in Cellular Neuroscience 2013791. (doi:10.3389/fncel.2013.00091)

27 Jedema HP \& Grace AA. Corticotropin-releasing hormone directly activates noradrenergic neurons of the locus ceruleus recorded in vitro. Journal of Neuroscience 200424 9703-9713. (doi:10.1523/ JNEUROSCI.2830-04.2004)

28 Tao J, Zhang Y, Soong TW \& Li S. Expression of urocortin 2 and its inhibitory effects on intracellular ca2+ via L-type voltagegated calcium channels in rat pheochromocytoma (PC12) cells. Neuropsychopharmacology 200631 2600-2609. (doi:10.1038/ sj.npp.1301123)

29 Kim Y, Park MK, Uhm DY \& Chung S. Modulation of T-type Ca2+ channels by corticotropin-releasing factor through protein kinase $\mathrm{C}$ pathway in MN9D dopaminergic cells. Biochemical and Biophysical Research Communications 2007358 796-801. (doi:10.1016/j. bbrc.2007.04.198)

30 Tao J, Hildebrand ME, Liao P, Liang MC, Tan G, Li S, Snutch TP \& Soong TW. Activation of corticotropin-releasing factor receptor 1 selectively inhibits CaV3.2 T-type calcium channels. Molecular Pharmacology 200873 1596-1609. (doi:10.1124/mol.107.043612)

31 Joels M \& Baram TZ. The neuro-symphony of stress. Nature Reviews: Neuroscience 200910 459-466. (doi:10.1038/nrn2632)

32 Chang CL \& Hsu SY. Ancient evolution of stress-regulating peptides in vertebrates. Peptides 200425 1681-1688. (doi:10.1016/j. peptides.2004.05.022)

33 Dautzenberg FM \& Hauger RL. The CRF peptide family and their receptors: yet more partners discovered. Trends in Pharmacological Sciences 200223 71-77. (doi:10.1016/S0165-6147(02)01946-6)

34 Waters RP, Rivalan M, Bangasser DA, Deussing JM, Ising M, Wood SK, Holsboer F \& Summers CH. Evidence for the role of corticotropin-releasing factor in major depressive disorder. Neuroscience and Biobehavioral Reviews 201558 63-78. (doi:10.1016/j. neubiorev.2015.07.011)

35 Gourcerol G, Wu SV, Yuan PQ, Pham H, Miampamba M, Larauche M, Sanders P, Amano T, Mulak A, Im E, et al. Activation of corticotropin-releasing factor receptor 2 mediates the colonic motor coping response to acute stress in rodents. Gastroenterology 2011140 1586.e1586-1596.e1586. (doi:10.1053/j.gastro.2011.01.039)
36 Hasdemir B, Mahajan S, Bunnett NW, Liao M \& Bhargava A. Endothelin-converting enzyme-1 actions determine differential trafficking and signaling of corticotropin-releasing factor receptor 1 at high agonist concentrations. Molecular Endocrinology 201226 681-695. (doi:10.1210/me.2011-1361)

37 Potter E, Behan DP, Fischer WH, Linton EA, Lowry PJ \& Vale WW. Cloning and characterization of the cDNAs for human and rat corticotropin releasing factor-binding proteins. Nature 1991349 423-426. (doi:10.1038/349423a0)

38 Westphal NJ \& Seasholtz AF. CRH-BP: the regulation and function of a phylogenetically conserved binding protein. Frontiers in Bioscience 200611 1878-1891. (doi:10.2741/1931)

39 Trainer PJ, Woods RJ, Korbonits M, Popovic V, Stewart PM, Lowry PJ \& Grossman AB. The pathophysiology of circulating corticotropinreleasing hormone-binding protein levels in the human. Journal of Clinical Endocrinology and Metabolism 199883 1611-1614. (doi:10.1210/jcem.83.5.4751)

40 Slater PG, Cerda CA, Pereira LA, Andres ME \& Gysling K. CRF binding protein facilitates the presence of CRF type 2alpha receptor on the cell surface. PNAS 2016113 4075-4080. (doi:10.1073/pnas.1523745113)

41 Lagerstrom MC \& Schioth HB. Structural diversity of G proteincoupled receptors and significance for drug discovery. Nature Reviews Drug Discovery 20087 339-357. (doi:10.1038/nrd2518)

42 Culhane KJ, Liu Y, Cai Y \& Yan EC. Transmembrane signal transduction by peptide hormones via family B G protein-coupled receptors. Frontiers in Pharmacology 20156 264. (doi:10.3389/ fphar.2015.00264)

43 Grace CR, Perrin MH, Gulyas J, Digruccio MR, Cantle JP, Rivier JE, Vale WW \& Riek R. Structure of the N-terminal domain of a type B1 $\mathrm{G}$ protein-coupled receptor in complex with a peptide ligand. PNAS 2007104 4858-4863. (doi:10.1073/pnas.0700682104)

44 Pioszak AA, Parker NR, Suino-Powell K \& Xu HE. Molecular recognition of corticotropin-releasing factor by its G-protein-coupled receptor CRFR1. Journal of Biological Chemistry 2008283 32900-32912. (doi:10.1074/jbc.M805749200)

45 Grace CR, Perrin MH, Gulyas J, Rivier JE, Vale WW \& Riek R. NMR structure of the first extracellular domain of corticotropin-releasing factor receptor 1 (ECD1-CRF-R1) complexed with a high affinity agonist. Journal of Biological Chemistry 2010285 38580-38589. (doi:10.1074/jbc.M110.121897)

46 Pal K, Swaminathan K, Xu HE \& Pioszak AA. Structural basis for hormone recognition by the Human CRFR2\{alpha\} G proteincoupled receptor. Journal of Biological Chemistry 2010285 40351-40361. (doi:10.1074/jbc.M110.186072)

47 Rutz C, Renner A, Alken M, Schulz K, Beyermann M, Wiesner B, Rosenthal W \& Schulein R. The corticotropin-releasing factor receptor type 2a contains an N-terminal pseudo signal peptide. Journal of Biological Chemistry 2006281 24910-24921. (doi:10.1074/ jbc.M601554200)

48 Schulz K, Rutz C, Westendorf C, Ridelis I, Vogelbein S, Furkert J, Schmidt A, Wiesner B \& Schulein R. The pseudo signal peptide of the corticotropin-releasing factor receptor type 2 a decreases receptor expression and prevents Gi-mediated inhibition of adenylyl cyclase activity. Journal of Biological Chemistry 2010285 32878-32887. (doi:10.1074/jbc.M110.129627)

49 Slater PG, Yarur HE \& Gysling K. Corticotropin-releasing factor receptors and their interacting proteins: functional consequences. Molecular Pharmacology 201690 627-632. (doi:10.1124/ mol.116.104927)

50 Gkountelias K, Tselios T, Venihaki M, Deraos G, Lazaridis I, Rassouli O, Gravanis A \& Liapakis G. Alanine scanning mutagenesis of the second extracellular loop of type 1 corticotropinreleasing factor receptor revealed residues critical for peptide binding. Molecular Pharmacology 200975 793-800. (doi:10.1124/ mol.108.052423) http://www.endocrineconnections.org DOI: 10.1530/EC-17-0111
(C) 2017 The authors Published by Bioscientifica Ltd

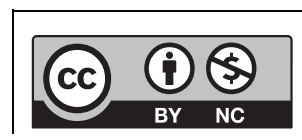

This work is licensed under a Creative Commons Attribution-NonCommercial 4.0 International License. 
51 Teichmann A, Rutz C, Kreuchwig A, Krause G, Wiesner B \& Schulein R. The Pseudo signal peptide of the corticotropin-releasing factor receptor type $2 \mathrm{~A}$ prevents receptor oligomerization. Journal of Biological Chemistry 2012287 27265-27274. (doi:10.1074/jbc.M112.360594)

52 Holsboer F \& Ising M. Stress hormone regulation: biological role and translation into therapy. Annual Review of Psychology 201061 C101-C111. (doi:10.1146/annurev.psych.093008.100321)

53 Beurel E \& Nemeroff CB. Interaction of stress, corticotropinreleasing factor, arginine vasopressin and behaviour Current Topics in Behavioral Neurosciences 201418 67-80. (doi:10.1007/7854_2014_306)

54 Birnbaumer M. Vasopressin receptors. Trends in Endocrinology and Metabolism 200011 406-410. (doi:10.1016/S1043-2760(00)00304-0)

55 Abou-Samra AB, Harwood JP, Manganiello VC, Catt KJ \& Aguilera G. Phorbol 12-myristate 13-acetate and vasopressin potentiate the effect of corticotropin-releasing factor on cyclic AMP production in rat anterior pituitary cells. Mechanisms of action. Journal of Biological Chemistry 1987262 1129-1136.

56 Cornett LE, Kang SW \& Kuenzel WJ. A possible mechanism contributing to the synergistic action of vasotocin (VT) and corticotropin-releasing hormone (CRH) receptors on corticosterone release in birds. General and Comparative Endocrinology 2013188 46-53. (doi:10.1016/j.ygcen.2013.02.032)

57 Mikhailova MV, Mayeux PR, Jurkevich A, Kuenzel WJ, Madison F, Periasamy A, Chen Y \& Cornett LE. Heterooligomerization between vasotocin and corticotropin-releasing hormone (CRH) receptors augments CRH-stimulated 3',5'-cyclic adenosine monophosphate production. Molecular Endocrinology 200721 2178-2188. (doi:10.1210/me.2007-0160)

58 Young SF, Griffante C \& Aguilera G. Dimerization between vasopressin $\mathrm{V} 1 \mathrm{~b}$ and corticotropin releasing hormone type 1 receptors. Cellular and Molecular Neurobiology 200727 439-461. (doi:10.1007/s10571-006-9135-8)

59 Murat B, Devost D, Andres M, Mion J, Boulay V, Corbani M, Zingg HH \& Guillon G. V1b and CRHR1 receptor heterodimerization mediates synergistic biological actions of vasopressin and CRH. Molecular Endocrinology 201226 502-520. (doi:10.1210/me.2011-1202)

60 Wanat MJ, Hopf FW, Stuber GD, Phillips PE \& Bonci A. Corticotropin-releasing factor increases mouse ventral tegmental area dopamine neuron firing through a protein kinase C-dependent enhancement of Ih. Journal of Physiology $2008 \mathbf{5 8 6} 2157-2170$. (doi:10.1113/jphysiol.2007.150078)

61 Hahn J, Hopf FW \& Bonci A. Chronic cocaine enhances corticotropin-releasing factor-dependent potentiation of excitatory transmission in ventral tegmental area dopamine neurons. Journal of Neuroscience 200929 6535-6544. (doi:10.1523/ JNEUROSCI.4773-08.2009)

62 Fuenzalida J, Galaz P, Araya KA, Slater PG, Blanco EH, Campusano JM, Ciruela F \& Gysling K. Dopamine D1 and corticotrophinreleasing hormone type-2alpha receptors assemble into functionally interacting complexes in living cells. British Journal of Pharmacology 2014171 5650-5664. (doi:10.1111/bph.12868)

63 Navarro G, Quiroz C, Moreno-Delgado D, Sierakowiak A, McDowell K, Moreno E, Rea W, Cai NS, Aguinaga D, Howell LA, et al. Orexincorticotropin-releasing factor receptor heteromers in the ventral tegmental area as targets for cocaine. Journal of Neuroscience 201535 6639-6653. (doi:10.1523/JNEUROSCI.4364-14.2015)

64 Magalhaes AC, Holmes KD, Dale LB, Comps-Agrar L, Lee D, Yadav PN, Drysdale L, Poulter MO, Roth BL, Pin JP, Anisman H $\&$ Ferguson SS. CRF receptor 1 regulates anxiety behavior via sensitization of 5-HT2 receptor signaling. Nature Neuroscience 2010 13 622-629. (doi:10.1038/nn.2529)

65 Markovic D, Punn A, Lehnert H \& Grammatopoulos DK. Intracellular mechanisms regulating corticotropin-releasing hormone receptor-2beta endocytosis and interaction with extracellularly regulated kinase $1 / 2$ and p38 mitogen-activated protein kinase signaling cascades. Molecular Endocrinology 200822 689-706. (doi:10.1210/me.2007-0136)

66 Bender J, Engeholm M, Ederer MS, Breu J, Moller TC, Michalakis S, Rasko T, Wanker EE, Biel M, Martinez KL, et al. Corticotropinreleasing hormone receptor type 1 (CRHR1) clustering with MAGUKs is mediated via its C-terminal PDZ binding motif. PLoS ONE $2015 \mathbf{1 0}$ e0136768. (doi:10.1371/journal.pone.0136768)

67 Dunn HA, Chahal HS, Caetano FA, Holmes KD, Yuan GY, Parikh R, Heit B \& Ferguson SS. PSD-95regulates CRFR1 localization, trafficking and beta-arrestin2 recruitment. Cellular Signalling 201628 531-540. (doi:10.1016/j.cellsig.2016.02.013)

68 Marcinkiewcz CA, Mazzone CM, D'Agostino G, Halladay LR, Hardaway JA, DiBerto JF, Navarro M, Burnham N, Cristiano C, Dorrier $\mathrm{CE}$, et al. Serotonin engages an anxiety and fear-promoting circuit in the extended amygdala. Nature 2016537 97-101. (doi:10.1038/nature19318)

69 Hollenstein K, Kean J, Bortolato A, Cheng RK, Dore AS, Jazayeri A, Cooke RM, Weir M \& Marshall FH. Structure of class B GPCR corticotropin-releasing factor receptor 1. Nature $2013499438-443$. (doi:10.1038/nature12357)

70 Siu FY, He M, de Graaf C, Han GW, Yang D, Zhang Z, Zhou C, Xu Q Wacker D, Joseph JS, et al. Structure of the human glucagon class B G-protein-coupled receptor. Nature 2013499 444-449. (doi:10.1038/ nature12393)

71 Wootten D, Miller LJ, Koole C, Christopoulos A \& Sexton PM. Allostery and biased agonism at class B G protein-coupled receptors. Chemical Reviews 2017117 111-138. (doi:10.1021/acs. chemrev.6b00049)

72 Liang YL, Khoshouei M, Radjainia M, Zhang Y, Glukhova A, Tarrasch J, Thal DM, Furness SGB, Christopoulos G, Coudrat T, et al. Phase-plate cryo-EM structure of a class B GPCR-G-protein complex. Nature 2017546 118-123. (doi:10.1038/nature22327)

73 Rosenbaum DM, Rasmussen SG \& Kobilka BK. The structure and function of G-protein-coupled receptors. Nature 2009459 356-363. (doi:10.1038/nature08144)

74 Latorraca NR, Venkatakrishnan AJ \& Dror RO. GPCR dynamics: structures in motion. Chemical Reviews 2017117 139-155. (doi:10.1021/acs.chemrev.6b00177)

75 Vilardaga JP, Jean-Alphonse FG \& Gardella TJ. Endosomal generation of cAMP in GPCR signaling. Nature Chemical Biology 201410 700-706. (doi:10.1038/nchembio.1611)

76 Irannejad R \& von Zastrow M. GPCR signaling along the endocytic pathway. Current Opinion in Cell Biology 201427 109-116. (doi:10.1016/j.ceb.2013.10.003)

77 Pavlos NJ \& Friedman PA. GPCR signaling and trafficking: the long and short of it. Trends in Endocrinology and Metabolism 201628 213-226. (doi:10.1016/j.tem.2016.10.007)

78 Grammatopoulos DK, Dai Y, Randeva HS, Levine MA, Karteris E, Easton AJ \& Hillhouse EW. A novel spliced variant of the type 1 corticotropin-releasing hormone receptor with a deletion in the seventh transmembrane domain present in the human pregnant term myometrium and fetal membranes. Molecular Endocrinology 199913 2189-2202. (doi:10.1210/mend.13.12.0391)

79 Papadopoulou N, Chen J, Randeva HS, Levine MA, Hillhouse EW \& Grammatopoulos DK. Protein kinase A-induced negative regulation of the corticotropin-releasing hormone R1alpha receptorextracellularly regulated kinase signal transduction pathway: the critical role of Ser301 for signaling switch and selectivity. Molecular Endocrinology 200418 624-639. (doi:10.1210/me.2003-0365)

80 Wietfeld D, Heinrich N, Furkert J, Fechner K, Beyermann M, Bienert $\mathrm{M} \&$ Berger H. Regulation of the coupling to different $\mathrm{G}$ proteins of rat corticotropin-releasing factor receptor type 1 in human embryonic kidney 293 cells. Journal of Biological Chemistry 2004279 38386-38394. (doi:10.1074/jbc.M405335200)

81 Scheerer P, Park JH, Hildebrand PW, Kim YJ, Krauss N, Choe HW, Hofmann KP \& Ernst OP. Crystal structure of opsin in its G-protein- http://www.endocrineconnections.org

DOI: 10.1530/EC-17-0111
(C) 2017 The authors Published by Bioscientifica Ltd
This work is licensed under a Creative Commons Attribution-NonCommercial 4.0 International License. 
interacting conformation. Nature $2008 \mathbf{4 5 5}$ 497-502. (doi:10.1038/ nature07330)

82 Choe HW, Kim YJ, Park JH, Morizumi T, Pai EF, Krauss N, Hofmann KP, Scheerer P \& Ernst OP. Crystal structure of metarhodopsin II. Nature 2011471 651-655. (doi:10.1038/nature09789)

83 Rasmussen SG, DeVree BT, Zou Y, Kruse AC, Chung KY, Kobilka TS, Thian FS, Chae PS, Pardon E, Calinski D, et al. Crystal structure of the beta2 adrenergic receptor-Gs protein complex. Nature 2011477 549-555. (doi:10.1038/nature10361)

84 Punn A, Chen J, Delidaki M, Tang J, Liapakis G, Lehnert H, Levine MA \& Grammatopoulos DK. Mapping structural determinants within third intracellular loop that direct signaling specificity of type 1 corticotropin-releasing hormone receptor. Journal of Biological Chemistry 2012287 8974-8985. (doi:10.1074/jbc.M111.272161)

85 Sutherland EW \& Rall TW. Fractionation and characterization of a cyclic adenine ribonucleotide formed by tissue particles. Journal of Biological Chemistry 1958232 1077-1091.

86 de Herder WW. Heroes in endocrinology: nobel prizes. Endocrine Connections 20143 R94-R104. (doi:10.1530/EC-14-0070)

87 Buxton IL \& Brunton LL. Compartments of cyclic AMP and protein kinase in mammalian cardiomyocytes. Journal of Biological Chemistry 1983258 10233-10239.

88 Teli T, Markovic D, Levine MA, Hillhouse EW \& Grammatopoulos DK. Regulation of corticotropin-releasing hormone receptor type 1alpha signaling: structural determinants for $G$ protein-coupled receptor kinase-mediated phosphorylation and agonist-mediated desensitization. Molecular Endocrinology 200519 474-490. (doi:10.1210/me.2004-0275)

89 Inda C, dos Santos Claro PA, Bonfiglio JJ, Senin SA, Maccarronex G, Turck CW \& Silberstein S. Different cAMP sources are critically involved in $\mathrm{G}$ protein-coupled receptor CRHR1 signaling. Journal of Cell Biology 2016214 181-195. (doi:10.1083/jcb.201512075)

90 Inda C, Bonfiglio JJ, dos Santos Claro PA, Senin SA, Armando NG, Deussing JM \& Silberstein S. cAMP-dependent cell differentiation triggered by activated CRHR1 in hippocampal neuronal cells. Scientific Reports 20177 1944. (doi:10.1038/s41598-017-02021-7)

91 Cooper DM \& Tabbasum VG. Adenylate cyclase-centred microdomains. Biochemical Journal 2014462 199-213. (doi:10.1042/BJ20140560)

92 Willoughby D \& Cooper DM. Organization and Ca2+ regulation of adenylyl cyclases in cAMP microdomains. Physiological Reviews 2007 87 965-1010. (doi:10.1152/physrev.00049.2006)

93 Chen Y, Cann MJ, Litvin TN, Iourgenko V, Sinclair ML, Levin LR $\&$ Buck J. Soluble adenylyl cyclase as an evolutionarily conserved bicarbonate sensor. Science 2000289 625-628. (doi:10.1126/ science.289.5479.625)

94 Jaiswal BS \& Conti M. Calcium regulation of the soluble adenylyl cyclase expressed in mammalian spermatozoa. PNAS 2003100 10676-10681. (doi:10.1073/pnas.1831008100)

95 Litvin TN, Kamenetsky M, Zarifyan A, Buck J \& Levin LR. Kinetic properties of 'soluble' adenylyl cyclase. Synergism between calcium and bicarbonate. Journal of Biological Chemistry 2003278 1592215926. (doi:10.1074/jbc.M212475200)

96 Tresguerres M, Levin LR \& Buck J. Intracellular cAMP signaling by soluble adenylyl cyclase. Kidney International 201179 1277-1288. (doi:10.1038/ki.2011.95)

97 Halm ST, Zhang J \& Halm DR. beta-Adrenergic activation of electrogenic $\mathrm{K}+$ and $\mathrm{Cl}-$ secretion in guinea pig distal colonic epithelium proceeds via separate cAMP signaling pathways. American Journal of Physiology: Gastrointestinal and Liver Physiology 2010299 G81-G95. (doi:10.1152/ajpgi.00035.2010)

98 Chen J, Martinez J, Milner TA, Buck J \& Levin LR. Neuronal expression of soluble adenylyl cyclase in the mammalian brain. Brain Research 20131518 1-8. (doi:10.1016/j.brainres.2013.04.027)

99 Stiles TL, Kapiloff MS \& Goldberg JL. The role of soluble adenylyl cyclase in neurite outgrowth. Biochimica et Biophysica Acta 2014 1842 2561-2568. (doi:10.1016/j.bbadis.2014.07.012)
100 Ivonnet P, Salathe M \& Conner GE. Hydrogen peroxide stimulation of CFTR reveals an Epac-mediated, soluble AC-dependent cAMP amplification pathway common to GPCR signalling. British Journal of Pharmacology 2015172 173-184. (doi:10.1111/bph.12934)

101 Zaccolo M \& Pozzan T. CAMP and $\mathrm{Ca}^{2+}$ interplay: a matter of oscillation patterns. Trends in Neurosciences 200326 53-55. (doi:10.1016/S0166-2236(02)00017-6)

102 Tojima T, Hines JH, Henley JR \& Kamiguchi H. Second messengers and membrane trafficking direct and organize growth cone steering. Nature Reviews: Neuroscience 201112 191-203. (doi:10.1038/nrn2996)

103 Kovalovsky D, Refojo D, Liberman AC, Hochbaum D, Pereda MP, Coso OA, Stalla GK, Holsboer F \& Arzt E. Activation and induction of NUR77/NURR1 in corticotrophs by CRH/cAMP: involvement of calcium, protein kinase A, and MAPK pathways. Molecular Endocrinology 200216 1638-1651. (doi:10.1210/mend.16.7.0863)

104 Markovic D, Punn A, Lehnert H \& Grammatopoulos DK. Molecular determinants and feedback circuits regulating type $2 \mathrm{CRH}$ receptor signal integration. Biochimica et Biophysica Acta 20111813 896-907. (doi:10.1016/j.bbamcr.2011.02.005)

105 Bonfiglio JJ, Inda C, Senin S, Maccarrone G, Refojo D, Giacomini D, Turck CW, Holsboer F, Arzt E \& Silberstein S. B-Raf and CRHR1 internalization mediate biphasic ERK1/2 activation by CRH in hippocampal HT22 Cells. Molecular Endocrinology 201327 491-510. (doi:10.1210/me.2012-1359)

106 Van Kolen K, Dautzenberg FM, Verstraeten K, Royaux I, De Hoogt R, Gutknecht E \& Peeters PJ. Corticotropin releasing factor-induced ERK phosphorylation in AtT20 cells occurs via a cAMP-dependent mechanism requiring EPAC2. Neuropharmacology 201058 135-144. (doi:10.1016/j.neuropharm.2009.06.022)

107 Bonfiglio JJ, Inda C, Refojo D, Holsboer F, Arzt E \& Silberstein S. The corticotropin-releasing hormone network and the hypothalamicpituitary-adrenal axis: molecular and cellular mechanisms involved. Neuroendocrinology 201194 12-20. (doi:10.1159/000328226)

108 Refojo D, Echenique C, Muller MB, Reul JM, Deussing JM, Wurst W, Sillaber I, Paez-Pereda M, Holsboer F \& Arzt E. Corticotropinreleasing hormone activates ERK1/2 MAPK in specific brain areas. PNAS 2005102 6183-6188. (doi:10.1073/pnas.0502070102)

109 Matallanas D, Birtwistle M, Romano D, Zebisch A, Rauch J, von Kriegsheim A \& Kolch W. Raf family kinases: old dogs have learned new tricks. Genes and Cancer 20112 232-260. (doi:10.1177/1947601911407323)

110 Baljuls A, Kholodenko BN \& Kolch W. It takes two to tangosignalling by dimeric Raf kinases. Molecular Biosystem 20139 551-558. (doi:10.1039/c2mb25393c)

111 Shenoy SK \& Lefkowitz RJ. beta-Arrestin-mediated receptor trafficking and signal transduction. Trends in Pharmacological Sciences 201132 521-533. (doi:10.1016/j.tips.2011.05.002)

112 Cibelli G, Corsi P, Diana G, Vitiello F \& Thiel G. Corticotropinreleasing factor triggers neurite outgrowth of a catecholaminergic immortalized neuron via cAMP and MAP kinase signalling pathways. European Journal of Neuroscience 200113 1339-1348. (doi:10.1046/j.0953-816x.2001.01510.x)

113 Emery AC, Eiden MV, Mustafa T \& Eiden LE. Rapgef2 connects GPCR-mediated cAMP signals to ERK activation in neuronal and endocrine cells. Science Signal 20136 ra51. (doi:10.1126/ scisignal.2003993)

114 Grammatopoulos DK, Randeva HS, Levine MA, Katsanou ES \& Hillhouse EW. Urocortin, but not corticotropin-releasing hormone (CRH), activates the mitogen-activated protein kinase signal transduction pathway in human pregnant myometrium: an effect mediated via R1alpha and R2beta CRH receptor subtypes and stimulation of Gq-proteins. Molecular Endocrinology 200014 2076-2091. (doi:10.1210/mend.14.12.0574)

115 Graziani G, Tentori L, Muzi A, Vergati M, Tringali G, Pozzoli G \& Navarra P. Evidence that corticotropin-releasing hormone inhibits cell growth of human breast cancer cells via the activation of CRH-

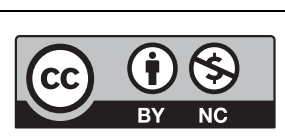

This work is licensed under a Creative Commons Attribution-NonCommercial 4.0 International License. 
R1 receptor subtype. Molecular and Cellular Endocrinology 2007264 44-49. (doi:10.1016/j.mce.2006.10.006)

116 Takai Y, Sasaki T \& Matozaki T. Small GTP-binding proteins. Physiological Reviews 200181 153-208.

117 Swinny JD \& Valentino RJ. Corticotropin-releasing factor promotes growth of brain norepinephrine neuronal processes through Rho GTPase regulators of the actin cytoskeleton in rat. European Journal of Neuroscience 200624 2481-2490. (doi:10.1111/j.14609568.2006.05129.x)

118 Swinny JD, Metzger F, IJkema-Paassen J, Gounko NV, Gramsbergen A \& van der Want JJ. Corticotropin-releasing factor and urocortin differentially modulate rat Purkinje cell dendritic outgrowth and differentiation in vitro. European Journal of Neuroscience 200419 1749-1758. (doi:10.1111/j.1460-9568.2004.03279.x)

119 Chen Y, Bender RA, Brunson KL, Pomper JK, Grigoriadis DE, Wurst W \& Baram TZ. Modulation of dendritic differentiation by corticotropin-releasing factor in the developing hippocampus. PNAS 2004101 15782-15787. (doi:10.1073/pnas.0403975101)

120 Gounko NV, Swinny JD, Kalicharan D, Jafari S, Corteen N, Seifi M, Bakels R \& van der Want JJ. Corticotropin-releasing factor and urocortin regulate spine and synapse formation: structural basis for stress-induced neuronal remodeling and pathology. Molecular Psychiatry 201318 86-92. (doi:10.1038/mp.2012.43)

121 Khan SM, Sleno R, Gora S, Zylbergold P, Laverdure JP, Labbe JC, Miller GJ \& Hebert TE. The expanding roles of Gbetagamma subunits in G protein-coupled receptor signaling and drug action. Pharmacological Reviews 201365 545-577. (doi:10.1124/pr.111.005603)

122 Sternweis PC. The purified alpha subunits of Go and Gi from bovine brain require beta gamma for association with phospholipid vesicles. Journal of Biological Chemistry 1986261 631-637.

123 Crespo P, Cachero TG, Xu N \& Gutkind JS. Dual effect of betaadrenergic receptors on mitogen-activated protein kinase. Evidence for a beta gamma-dependent activation and a G alpha s-cAMPmediated inhibition. Journal of Biological Chemistry 1995270 25259-25265. (doi:10.1074/jbc.270.42.25259)

124 Crespo P, Xu N, Simonds WF \& Gutkind JS. Ras-dependent activation of MAP kinase pathway mediated by G-protein beta gamma subunits. Nature 1994369 418-420. (doi:10.1038/369418a0)

125 Coso OA, Teramoto H, Simonds WF \& Gutkind JS. Signaling from $\mathrm{G}$ protein-coupled receptors to c-Jun kinase involves beta gamma subunits of heterotrimeric $\mathrm{G}$ proteins acting on a Ras and Rac1-dependent pathway. Journal of Biological Chemistry 1996271 3963-3966. (doi:10.1074/jbc.271.8.3963)

126 Punn A, Levine MA \& Grammatopoulos DK. Identification of signaling molecules mediating corticotropin-releasing hormoneR1alpha-mitogen-activated protein kinase (MAPK) interactions: the critical role of phosphatidylinositol 3-kinase in regulating ERK1/2 but not p38 MAPK activation. Molecular Endocrinology 200620 3179-3195. (doi:10.1210/me.2006-0255)

127 Stern CM, Meitzen J \& Mermelstein PG. Corticotropin-releasing factor and urocortin I activate CREB through functionally selective Gbetagamma signaling in hippocampal pyramidal neurons. European Journal of Neuroscience 201134 671-681. (doi:10.1111/j.14609568.2011.07812.x)

128 Stern CM, Luoma JI, Meitzen J \& Mermelstein PG. Corticotropin releasing factor-induced CREB activation in striatal neurons occurs via a novel Gbetagamma signaling pathway. PLoS ONE 20116 e18114. (doi:10.1371/journal.pone.0018114)

129 Wehbi VL, Stevenson HP, Feinstein TN, Calero G, Romero G \& Vilardaga JP. Noncanonical GPCR signaling arising from a PTH receptor-arrestin-Gbetagamma complex. PNAS 2013110 1530-1535. (doi:10.1073/pnas.1205756110)

130 Jean-Alphonse FG, Wehbi VL, Chen J, Noda M, Taboas JM, Xiao K \& Vilardaga JP. beta2-adrenergic receptor control of endosomal PTH receptor signaling via Gbetagamma. Nature Chemical Biology 201713 259-261. (doi:10.1038/nchembio.2267)
131 Sigismund S, Confalonieri S, Ciliberto A, Polo S, Scita G \& Di Fiore PP. Endocytosis and signaling: cell logistics shape the eukaryotic cell plan. Physiological Reviews 201292 273-366. (doi:10.1152/ physrev.00005.2011)

132 Refojo D, Schweizer M, Kuehne C, Ehrenberg S, Thoeringer C, Vogl AM, Dedic N, Schumacher M, von Wolff G, Avrabos C, et al. Glutamatergic and dopaminergic neurons mediate anxiogenic and anxiolytic effects of CRHR1. Science 2011333 1903-1907. (doi:10.1126/science.1202107)

133 Holmes KD, Babwah AV, Dale LB, Poulter MO \& Ferguson SS. Differential regulation of corticotropin releasing factor 1alpha receptor endocytosis and trafficking by beta-arrestins and Rab GTPases. Journal of Neurochemistry 200696 934-949. (doi:10.1111/ j.1471-4159.2005.03603.x)

134 Hauger RL, Olivares-Reyes JA, Braun S, Hernandez-Aranda J, Hudson CC, Gutknecht E, Dautzenberg FM \& Oakley RH. Desensitization of human CRF2(a) receptor signaling governed by agonist potency and betaarrestin2 recruitment. Regulatory Peptides 2013186 62-76. (doi:10.1016/j.regpep.2013.06.009)

135 Gutknecht E, Hauger RL, Van der Linden I, Vauquelin G \& Dautzenberg FM. Expression, binding, and signaling properties of CRF2(a) receptors endogenously expressed in human retinoblastoma Y79 cells: passagedependent regulation of functional receptors. Journal of Neurochemistry 2008 104 926-936. (doi:10.1111/j.1471-4159.2007.05052.x)

136 Valentino RJ, Van Bockstaele E \& Bangasser D. Sex-specific cell signaling: the corticotropin-releasing factor receptor model. Trends in Pharmacological Sciences 201334 437-444. (doi:10.1016/j. tips.2013.06.004)

137 Kubat E, Mahajan S, Liao M, Ackerman L, Ohara PT, Grady EF \& Bhargava A. Corticotropin-releasing factor receptor 2 mediates sex-specific cellular stress responses. Molecular Medicine 201319 212-222. (doi:10.2119/molmed.2013.00036)

138 Hasdemir B, Mhaske P, Paruthiyil S, Garnett EA, Heyman MB, Matloubian M \& Bhargava A. Sex- and corticotropin-releasing factor receptor 2- dependent actions of urocortin 1 during inflammation. American Journal of Physiology: Regulatory, Integrative and Comparative Physiology 2016310 R1244-R1257. (doi:10.1152/ ajpregu.00445.2015)

139 Benovic JL, Mayor F, Jr., Somers RL, Caron MG \& Lefkowitz RJ. Light-dependent phosphorylation of rhodopsin by beta-adrenergic receptor kinase. Nature 1986321 869-872. (doi:10.1038/321869a0)

140 Moore CA, Milano SK \& Benovic JL. Regulation of receptor trafficking by GRKs and arrestins. Annual Review of Physiology 2007 69 451-482. (doi:10.1146/annurev.physiol.69.022405.154712)

141 Dautzenberg FM, Braun S \& Hauger RL. GRK3 mediates desensitization of CRF1 receptors: a potential mechanism regulating stress adaptation. American Journal of Physiology: Regulatory, Integrative and Comparative Physiology 2001280 R935-R946.

142 Kageyama K, Hanada K, Moriyama T, Nigawara T, Sakihara S $\&$ Suda T. G protein-coupled receptor kinase 2 involvement in desensitization of corticotropin-releasing factor (CRF) receptor type 1 by CRF in murine corticotrophs. Endocrinology 2006147 441-450. (doi:10.1210/en.2005-0376)

143 Perry SJ, Junger S, Kohout TA, Hoare SR, Struthers RS, Grigoriadis DE \& Maki RA. Distinct conformations of the corticotropin releasing factor type 1 receptor adopted following agonist and antagonist binding are differentially regulated. Journal of Biological Chemistry 2005280 11560-11568. (doi:10.1074/jbc. M412914200)

144 Hauger RL, Dautzenberg FM, Flaccus A, Liepold T \& Spiess J. Regulation of corticotropin-releasing factor receptor function in human Y-79 retinoblastoma cells: rapid and reversible homologous desensitization but prolonged recovery. Journal of Neurochemistry 199768 2308-2316. (doi:10.1046/j.1471-4159.1997.68062308.x)

145 Roseboom PH, Urben CM \& Kalin NH. Persistent corticotropinreleasing factor (1) receptor desensitization and downregulation in the

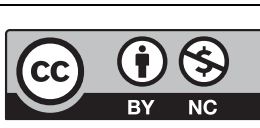

This work is licensed under a Creative Commons Attribution-NonCommercial 4.0 International License. 
human neuroblastoma cell line IMR-32. Brain Research: Molecular Brain Research 200192 115-127. (doi:10.1016/S0169-328X(01)00162-0)

146 Oakley RH, Olivares-Reyes JA, Hudson CC, Flores-Vega F, Dautzenberg FM \& Hauger RL. Carboxyl-terminal and intracellular loop sites for CRF1 receptor phosphorylation and beta-arrestin-2 recruitment: a mechanism regulating stress and anxiety responses. American Journal of Physiology: Regulatory, Integrative and Comparative Physiology 2007293 R209-R222. (doi:10.1152/ ajpregu.00099.2006)

147 Goodman OB Jr, Krupnick JG, Santini F, Gurevich VV, Penn RB, Gagnon AW, Keen JH \& Benovic JL. Beta-arrestin acts as a clathrin adaptor in endocytosis of the beta2-adrenergic receptor. Nature 1996 383 447-450. (doi:10.1038/383447a0)

148 Gurevich VV \& Gurevich EV. Arrestins: critical players in trafficking of many GPCRs. Progress in Molecular Biology and Translational Science 2015132 1-14. (doi:10.1016/bs.pmbts.2015.02.010)

149 Luttrell LM, Ferguson SS, Daaka Y, Miller WE, Maudsley S, Della Rocca GJ, Lin F, Kawakatsu H, Owada K, Luttrell DK, et al. Betaarrestin-dependent formation of beta2 adrenergic receptor-Src protein kinase complexes. Science 1999283 655-661. (doi:10.1126/ science.283.5402.655)

150 Shenoy SK, Drake MT, Nelson CD, Houtz DA, Xiao K, Madabushi S, Reiter E, Premont RT, Lichtarge O \& Lefkowitz RJ. Beta-arrestindependent, $\mathrm{G}$ protein-independent ERK1/2 activation by the beta2 adrenergic receptor. Journal of Biological Chemistry $2006 \mathbf{2 8 1}$ 1261-1273. (doi:10.1074/jbc.M506576200)

151 Rasmussen TN, Novak I \& Nielsen SM. Internalization of the human CRF receptor 1 is independent of classical phosphorylation sites and of beta-arrestin 1 recruitment. European Journal of Biochemistry 2004 271 4366-4374. (doi:10.1111/j.1432-1033.2004.04371.x)

152 Bangasser DA, Curtis A, Reyes BA, Bethea TT, Parastatidis I, Ischiropoulos H, Van Bockstaele EJ \& Valentino RJ. Sex differences in corticotropin-releasing factor receptor signaling and trafficking: potential role in female vulnerability to stress-related psychopathology. Molecular Psychiatry 201015 877, 896-904. (doi:10.1038/mp.2010.66)

153 DeFea KA, Vaughn ZD, O’Bryan EM, Nishijima D, Dery O \& Bunnett NW. The proliferative and antiapoptotic effects of substance $\mathrm{P}$ are facilitated by formation of a beta -arrestin-dependent scaffolding complex. PNAS 200097 11086-11091. (doi:10.1073/ pnas.190276697)

154 Ahn S, Shenoy SK, Wei H \& Lefkowitz RJ. Differential kinetic and spatial patterns of beta-arrestin and G protein-mediated ERK activation by the angiotensin II receptor. Journal of Biological Chemistry 2004279 35518-35525. (doi:10.1074/jbc.M405878200)

155 Ge L, Ly Y, Hollenberg M \& DeFea K. A beta-arrestin-dependent scaffold is associated with prolonged MAPK activation in pseudopodia during protease-activated receptor-2-induced chemotaxis. Journal of Biological Chemistry 2003278 34418-34426. (doi:10.1074/jbc.M300573200)

156 Hunton DL, Barnes WG, Kim J, Ren XR, Violin JD, Reiter E, Milligan G, Patel DD \& Lefkowitz RJ. Beta-arrestin 2-dependent angiotensin II type 1A receptor-mediated pathway of chemotaxis. Molecular Pharmacology 200567 1229-1236. (doi:10.1124/ mol.104.006270)

157 Patel PA, Tilley DG \& Rockman HA. Physiologic and cardiac roles of beta-arrestins. Journal of Molecular and Cellular Cardiology 200946 300-308. (doi:10.1016/j.yjmcc.2008.11.015)

158 Nuber S, Zabel U, Lorenz K, Nuber A, Milligan G, Tobin AB, Lohse MJ \& Hoffmann C. beta-Arrestin biosensors reveal a rapid, receptordependent activation/deactivation cycle. Nature 2016531 661-664. (doi:10.1038/nature17198)

159 Lee MH, Appleton KM, Strungs EG, Kwon JY, Morinelli TA, Peterson YK, Laporte SA \& Luttrell LM. The conformational signature of beta-arrestin 2 predicts its trafficking and signalling functions. Nature 2016531 665-668. (doi:10.1038/nature17154)
160 Eichel K, Jullie D \& von Zastrow M. beta-Arrestin drives MAP kinase signalling from clathrin-coated structures after GPCR dissociation. Nature Cell Biology 201618 303-310. (doi:10.1038/ncb3307)

161 Magalhaes AC, Dunn H \& Ferguson SS. Regulation of GPCR activity, trafficking and localization by GPCR-interacting proteins. British Journal of Pharmacology 2012165 1717-1736. (doi:10.1111/j.14765381.2011.01552.x)

162 Couvineau A \& Laburthe M. The family B1 GPCR: structural aspects and interaction with accessory proteins. Current Drug Targets 201213 103-115. (doi:10.2174/138945012798868434)

163 Slessareva JE, Routt SM, Temple B, Bankaitis VA \& Dohlman HG. Activation of the phosphatidylinositol 3-kinase Vps34 by a G protein alpha subunit at the endosome. Cell 2006126 191-203. (doi:10.1016/j.cell.2006.04.045)

164 Ferrandon S, Feinstein TN, Castro M, Wang B, Bouley R, Potts JT, Gardella TJ \& Vilardaga JP. Sustained cyclic AMP production by parathyroid hormone receptor endocytosis. Nature Chemical Biology 20095 734-742. (doi:10.1038/nchembio.206)

165 Calebiro D, Nikolaev VO, Gagliani MC, de Filippis T, Dees C, Tacchetti C, Persani L \& Lohse MJ. Persistent cAMP-signals triggered by internalized G-protein-coupled receptors. PLoS Biology 20097 e1000172. (doi:10.1371/journal.pbio.1000172)

166 Mullershausen F, Zecri F, Cetin C, Billich A, Guerini D \& Seuwen K. Persistent signaling induced by FTY720-phosphate is mediated by internalized S1P1 receptors. Nature Chemical Biology 20095 428-434. (doi:10.1038/nchembio.173)

167 Kuna RS, Girada SB, Asalla S, Vallentyne J, Maddika S, Patterson JT, Smiley DL, DiMarchi RD \& Mitra P. Glucagon-like peptide-1 receptor-mediated endosomal cAMP generation promotes glucosestimulated insulin secretion in pancreatic beta-cells. American Journal of Physiology: Endocrinology and Metabolism 2013305 E161-E170. (doi:10.1152/ajpendo.00551.2012)

168 Merriam LA, Baran CN, Girard BM, Hardwick JC, May V \& Parsons RL. Pituitary adenylate cyclase 1 receptor internalization and endosomal signaling mediate the pituitary adenylate cyclase activating polypeptide-induced increase in guinea pig cardiac neuron excitability. Journal of Neuroscience 201333 4614-4622. (doi:10.1523/JNEUROSCI.4999-12.2013)

169 Feinstein TN, Yui N, Webber MJ, Wehbi VL, Stevenson HP, King JD Jr, Hallows KR, Brown D, Bouley R \& Vilardaga JP. Noncanonical control of vasopressin receptor type 2 signaling by retromer and arrestin. Journal of Biological Chemistry 2013288 27849-27860. (doi:10.1074/jbc.M112.445098)

170 Kotowski SJ, Hopf FW, Seif T, Bonci A \& von Zastrow M. Endocytosis promotes rapid dopaminergic signaling. Neuron 201171 278-290. (doi:10.1016/j.neuron.2011.05.036)

171 Irannejad R, Tomshine JC, Tomshine JR, Chevalier M, Mahoney JP, Steyaert J, Rasmussen SG, Sunahara RK, El-Samad H, Huang B \& von Zastrow M. Conformational biosensors reveal GPCR signalling from endosomes. Nature 2013495 534-538. (doi:10.1038/ nature12000)

172 Tsvetanova NG \& von Zastrow M. Spatial encoding of cyclic AMP signaling specificity by GPCR endocytosis. Nature Chemical Biology 201410 1061-1065. (doi:10.1038/nchembio.1665)

173 Shukla AK, Westfield GH, Xiao K, Reis RI, Huang LY, Tripathi-Shukla P, Qian J, Li S, Blanc A, Oleskie AN, et al. Visualization of arrestin recruitment by a G-protein-coupled receptor. Nature $2014 \mathbf{5 1 2}$ 218-222. (doi:10.1038/nature13430)

174 Szczepek M, Beyriere F, Hofmann KP, Elgeti M, Kazmin R, Rose A, Bartl FJ, von Stetten D, Heck M, Sommer ME, et al. Crystal structure of a common GPCR-binding interface for $\mathrm{G}$ protein and arrestin. Nature Communications 20145 4801. (doi:10.1038/ncomms5801)

175 Kang Y, Zhou XE, Gao X, He Y, Liu W, Ishchenko A, Barty A, White TA, Yefanov O, Han GW, et al. Crystal structure of rhodopsin bound to arrestin by femtosecond X-ray laser. Nature $2015 \mathbf{5 2 3} 561-567$. (doi:10.1038/nature14656)

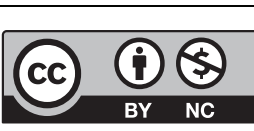

This work is licensed under a Creative Commons Attribution-NonCommercial 4.0 International License. 
176 Thomsen AR, Plouffe B, Cahill TJ 3rd, Shukla AK, Tarrasch JT, Dosey AM, Kahsai AW, Strachan RT, Pani B, Mahoney JP, et al. GPCR-G protein-beta-arrestin super-complex mediates sustained $G$ protein signaling. Cell 2016166 907-919. (doi:10.1016/j.cell.2016.07.004)

177 Feinstein TN, Wehbi VL, Ardura JA, Wheeler DS, Ferrandon S, Gardella TJ \& Vilardaga JP. Retromer terminates the generation of cAMP by internalized PTH receptors. Nature Chemical Biology 20117 278-284. (doi:10.1038/nchembio.545)

178 Caldieri G \& Sigismund S. Spatial resolution of cAMP signaling by soluble adenylyl cyclase. Journal of Cell Biology 2016214 125-127. (doi:10.1083/jcb.201606123)

179 Bowman SL, Shiwarski DJ \& Puthenveedu MA. Distinct G proteincoupled receptor recycling pathways allow spatial control of downstream G protein signaling. Journal of Cell Biology 2016214 797-806. (doi:10.1083/jcb.201512068)

180 Wang G, Wei Z \& Wu G. Role of Rab GTPases in the export trafficking of G protein-coupled receptors. Small GTPases 2017 1-6. (doi:10.1080/21541248.2016.1277000)

181 Gidon A, Al-Bataineh MM, Jean-Alphonse FG, Stevenson HP, Watanabe T, Louet C, Khatri A, Calero G, Pastor-Soler NM, Gardella TJ, et al. Endosomal GPCR signaling turned off by negative feedback actions of PKA and v-ATPase. Nature Chemical Biology 201410 707-709. (doi:10.1038/nchembio.1589)

182 Milan-Lobo L, Gsandtner I, Gaubitzer E, Runzler D, Buchmayer F, Kohler G, Bonci A, Freissmuth M \& Sitte HH. Subtype-specific differences in corticotropin-releasing factor receptor complexes detected by fluorescence spectroscopy. Molecular Pharmacology 2009 76 1196-1210. (doi:10.1124/mol.109.059139)

183 Watson RL, Buck J, Levin LR, Winger RC, Wang J, Arase H \& Muller WA. Endothelial CD99 signals through soluble adenylyl cyclase and PKA to regulate leukocyte transendothelial migration. Journal of Experimental Medicine 2015212 1021-1041. (doi:10.1084/jem.20150354)

184 Namkung Y, Le Gouill C, Lukashova V, Kobayashi H, Hogue M, Khoury E, Song M, Bouvier M \& Laporte SA. Monitoring G proteincoupled receptor and beta-arrestin trafficking in live cells using enhanced bystander BRET. Nature Communications 2016712178. (doi:10.1038/ncomms12178)

185 Lohse MJ \& Calebiro D. Cell biology: receptor signals come in waves. Nature 2013495 457-458. (doi:10.1038/nature12086)

186 van Gaalen MM, Stenzel-Poore MP, Holsboer F \& Steckler T. Effects of transgenic overproduction of $\mathrm{CRH}$ on anxiety-like behaviour. European Journal of Neuroscience 200215 2007-2015. (doi:10.1046/ j.1460-9568.2002.02040.x)

187 Griebel G \& Holsboer F. Neuropeptide receptor ligands as drugs for psychiatric diseases: the end of the beginning? Nature Reviews Drug Discovery 201211 462-478. (doi:10.1038/nrd3702)

188 Zorrilla EP, Valdez GR, Nozulak J, Koob GF \& Markou A. Effects of antalarmin, a CRF type 1 receptor antagonist, on anxiety-like behavior and motor activation in the rat. Brain Research 2002952 188-199. (doi:10.1016/S0006-8993(02)03189-X)

189 Timpl P, Spanagel R, Sillaber I, Kresse A, Reul JM, Stalla GK, Blanquet V, Steckler T, Holsboer F \& Wurst W. Impaired stress response and reduced anxiety in mice lacking a functional corticotropin-releasing hormone receptor 1. Nature Genetics 199819 162-166. (doi:10.1038/520)

190 Bale TL, Contarino A, Smith GW, Chan R, Gold LH, Sawchenko PE, Koob GF, Vale WW \& Lee KF. Mice deficient for corticotropin-releasing hormone receptor-2 display anxiety-like behaviour and are hypersensitive to stress. Nature Genetics 200024 410-414. (doi:10.1038/74263)

191 Coste SC, Kesterson RA, Heldwein KA, Stevens SL, Heard AD, Hollis JH, Murray SE, Hill JK, Pantely GA, Hohimer AR, et al. Abnormal adaptations to stress and impaired cardiovascular function in mice lacking corticotropin-releasing hormone receptor-2. Nature Genetics 200024 403-409. (doi:10.1038/74255)

192 Neufeld-Cohen A, Tsoory MM, Evans AK, Getselter D, Gil S, Lowry CA, Vale WW \& Chen A. A triple urocortin knockout mouse model reveals an essential role for urocortins in stress recovery. PNAS 2010 107 19020-19025. (doi:10.1073/pnas.1013761107)

193 Shemesh Y, Forkosh O, Mahn M, Anpilov S, Sztainberg Y, Manashirov S, Shlapobersky T, Elliott E, Tabouy L, Ezra G, et al. Ucn3 and CRF-R2 in the medial amygdala regulate complex social dynamics. Nature Neuroscience 201619 1489-1496. (doi:10.1038/nn.4346)

194 Regev L \& Baram TZ. Corticotropin releasing factor in neuroplasticity. Frontiers in Neuroendocrinology 201435 171-179. (doi:10.1016/j.yfrne.2013.10.001)

195 Lemos JC, Wanat MJ, Smith JS, Reyes BA, Hollon NG, Van Bockstaele EJ, Chavkin C \& Phillips PE. Severe stress switches CRF action in the nucleus accumbens from appetitive to aversive. Nature $2012 \mathbf{4 9 0}$ 402-406. (doi:10.1038/nature11436)

196 Holsboer F. The rationale for corticotropin-releasing hormone receptor (CRH-R) antagonists to treat depression and anxiety. Journal of Psychiatric Research 199933 181-214. (doi:10.1016/S0022-3956(98)90056-5)

197 Binder EB \& Nemeroff CB. The CRF system, stress, depression and anxiety-insights from human genetic studies. Molecular Psychiatry 201015 574-588. (doi:10.1038/mp.2009.141)

198 Zorrilla EP, Logrip ML \& Koob GF. Corticotropin releasing factor: a key role in the neurobiology of addiction. Frontiers in Neuroendocrinology 201435 234-244. (doi:10.1016/j.yfrne.2014.01.001)

199 Raglan GB, Schmidt LA \& Schulkin J. The role of glucocorticoids and corticotropin-releasing hormone regulation on anxiety symptoms and response to treatment. Endocrine Connections 20176 R1-R7. (doi:10.1530/EC-16-0100)

200 Arborelius L, Owens MJ, Plotsky PM \& Nemeroff CB. The role of corticotropin-releasing factor in depression and anxiety disorders. Journal of Endocrinology 1999160 1-12. (doi:10.1677/joe.0.1600001)

201 Nemeroff CB, Widerlov E, Bissette G, Walleus H, Karlsson I, Eklund $\mathrm{K}$, Kilts CD, Loosen PT \& Vale W. Elevated concentrations of CSF corticotropin-releasing factor-like immunoreactivity in depressed patients. Science 1984226 1342-1344. (doi:10.1126/science.6334362)

202 Bremner JD, Licinio J, Darnell A, Krystal JH, Owens MJ, Southwick SM, Nemeroff CB \& Charney DS. Elevated CSF corticotropin-releasing factor concentrations in posttraumatic stress disorder. American Journal of Psychiatry 1997154 624-629. (doi:10.1176/ajp.154.5.624)

203 De Bellis MD, Gold PW, Geracioti TD Jr, Listwak SJ \& Kling MA. Association of fluoxetine treatment with reductions in CSF concentrations of corticotropin-releasing hormone and arginine vasopressin in patients with major depression. American Journal of Psychiatry 1993150 656-657. (doi:10.1176/ajp.150.4.656)

204 Heuser I, Bissette G, Dettling M, Schweiger U, Gotthardt U, Schmider J, Lammers CH, Nemeroff CB \& Holsboer F. Cerebrospinal fluid concentrations of corticotropin-releasing hormone, vasopressin, and somatostatin in depressed patients and healthy controls: response to amitriptyline treatment. Depression and Anxiety 19988 71-79. (doi:10.1002/(SICI)1520-6394(1998)8:2<71::AID-DA5>3.0.CO;2-N)

205 Merali Z, Du L, Hrdina P, Palkovits M, Faludi G, Poulter MO \& Anisman H. Dysregulation in the suicide brain: mRNA expression of corticotropin-releasing hormone receptors and GABA(A) receptor subunits in frontal cortical brain region. Journal of Neuroscience 2004 24 1478-1485. (doi:10.1523/JNEUROSCI.4734-03.2004)

206 Byers AL \& Yaffe K. Depression and risk of developing dementia. Nature Reviews: Neurology 20117 323-331. (doi:10.1038/nrneurol.2011.60)

Received in final form 11 July 2017

Accepted 14 July 2017

Accepted Preprint published online 14 July 2017 http://www.endocrineconnections.org DOI: 10.1530/EC-17-0111 (c) 2017 The authors Published by Bioscientifica Ltd

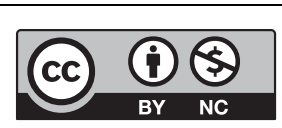

This work is licensed under a Creative Commons Attribution-NonCommercial 4.0 International License. 